Originally published as:

Steinhoefel, G., Hegner, E., Oliver, G. J. H. (2008): Chemical and Nd isotope constraints on granitoid sources involved in the Caledonian Orogeny in Scotland. - Journal of the Geological Society, 165, 4, 817-827

DOI: 10.1144/0016-76492007-107 


\title{
Chemical and Nd isotope constraints on granitoid sources involved in the Caledonian orogeny in Scotland
}

\author{
Journal of the Geological Society, doi:10.1144/0016-76492007-107 \\ Grit Steinhoefel $^{\mathrm{a}, *}$, Ernst Hegner ${ }^{\mathrm{a}}$, Grahame J. H. Oliver ${ }^{\mathrm{b}}$
}

\begin{abstract}
${ }^{\mathrm{a} D e p a r t m e n t ~ f u ̈ r ~ G e o-~ u n d ~ U m w e l t w i s s e n s c h a f t e n, ~ U n i v e r s i t a ̈ t ~ M u ̈ n c h e n, ~ T h e r e s i e n s t r . ~ 41, ~ D-80333 ~}$ München, Germany

${ }^{\mathrm{b} C}$ rustal Geodynamics Group, School of Geography and Geosciences, University of St. Andrews, Irving Building, St. Andrews, Scotland, KY16 9AL
\end{abstract}

*Corresponding author. Present address: Institut für Mineralogie, Universität Hannover, Callinstr. 3, D-30167 Hannover, Germany. Tel.: +49 (0)511 762-8970; fax: +49 (0)511 762-2110.

E-mail address: g.steinhoefel@mineralogie.uni-hannover.de (Grit Steinhoefel)

\begin{abstract}
Major- and trace-element data and Nd isotope compositions for granitoid samples from the Grampian Highlands in Scotland, show a systematic evolution in the composition of their sources in course of the Caledonian Orogeny. 511 to 451 Ma old granitoids, related to the collision of the Midland Valley island arc with the Grampian terrane, show S-type affinity and fractionated REE patterns with minor Eu-anomalies and low initial $\varepsilon_{\mathrm{Nd}}$ values of -14.1 to -11.2 suggesting melting of predominantly Dalradian metasediments. Subsequently formed granitoids of 425 to 406 Ma derived from an assumed Andean plate margin comprise a wide spectrum of rock types including I-type granite-granodiorite, and S-type granitoids, monzonites, as well as alkali granites. The trace-element patterns of these rocks and a range of initial $\varepsilon_{\mathrm{Nd}}$ values of -2.1 to -6.9 consistent with melting variably rejuvenated crust as found in continental margin settings. We conclude that the Grampian Highlands were affected by two major crust-modifying events during the Caledonian Orogeny: predominantly recycling of older crust during docking of the Midland Valley arc and addition of juvenile material to the crust during the convergence of Avalonia with Laurentia. The latter event resulted in significant additions of juvenile mantlederived material to the crust.
\end{abstract}

\section{Introduction}

The granitoids of the Grampian Highlands form an important member of the Caledonian mountain belt of Scotland and Ireland. They have been interpreted as originating from the Caledonian orogenic cycle from $~ 600$ to 395 Ma beginning with continental rifting and opening of the Iapetus Ocean, arc-continent collision and subsequent subduction, as well as final plate collision (see reviews of e.g. Stephenson \& Gould 1995; Oliver 2003; Strachan et al. 2003). Thus the Grampian Highlands present a field laboratory to develop and test models for the geodynamic evolution of the margin of Laurentia as well as the Caledonian Orogeny. In the Grampian Highlands widespread magmatism was caused by the collision of an island arc with the passive Laurentia margin, known as the Grampian Orogeny, and subsequent plate subduction beneath the accreted arc. Granitic rocks produced during these stages provide petrographical, geochemical, and isotope evidence for melting of compositionally different sources as the Caledonian Orogeny was underway (e.g. Brown 1979; Harmon et al. 1984; Stephens \& Halliday 1984; Halliday 1984; Thirlwall 1988).

A drawback of the earlier studies of the granitoids of the Grampian Highlands is the fact that in many cases geochronological, isotope or geochemical data were interpreted independently due to the lack of comprehensive geochemical-isotope data sets. To date many plutons are known on a reconnaissance basis only and their apparently complex petrogenesis together with potential magma sources needs still to be investigated in more detail. In this study, we interpret major- and trace-element data as well as Sm-Nd isotope systematics in granitoid samples related to the collision of the Midland Valley arc with Laurentia and the subsequent subduction of oceanic lithosphere when Avalonia converged with Laurentia. Age constraints on the igneous events and emplacement of the samples of this study are provided by new ion-microprobe zircon ages presented in a companion paper (Oliver et al. 2008). 


\section{Geological background}

The Caledonian mountain belt of Scotland forms a continuation of the Appalachian mountain belt in North America. It consists of terranes that were assembled at the Laurentian margin during closure of the Iapetus Ocean (e.g. Bluck 2001; Fig. 1a, c). During the early phase of the Caledonian Orogeny from ca. 470 to $460 \mathrm{Ma}$ (e.g. Dewey \& Mange 1999; Oliver 2001; Flowerdew et al. 2005), the continent-facing Midland Valley arc, in Scotland now presumably buried in the Midland Valley terrane, collided with the Grampian terrane. This led to the Grampian Orogeny in Scotland and Ireland. The orogeny corresponds to the Taconian phase in North America. The accretion of the Midland Valley arc caused deformation, high-grade regional metamorphism, and magmatism, especially in the Grampian Highlands. After the arc-continent collision, continental convergence was facilitated by plate subduction under Laurentia, which is known as the Scandian phase. It ceased with the closure of the Iapetus Ocean and soft docking of Avalonia.

The origin of the Caledonian granitoids of the Grampian Highlands has been a reoccurring issue in geological studies for more than a century. Structural analyses going back to Barrow (1893) yielded a general division into metamorphosed and deformed as well as undeformed granitoids. The two groups were termed as "Older Granites" and "Newer Granites”, respectively by Read (1961). Based on structural and geochemical evidence the Caledonian granitoids have been assigned to pre-tectonic, syn-tectonic, late-tectonic and post-tectonic stages of the Grampian Orogeny (see review of Stephenson \& Gould 1995). The Grampian terrane comprises a preDalradian basement, overlain by Dalradian metasedimentary rocks, as well as the crosscutting Caledonian granitoids (Fig. 1b, c). The basement of the Grampian terrane is not exposed in the Grampian Highlands, but is thought to occur as the ca. 1.8 Ga Rhinns Complex on Islay and Colonsay of the Inner Hebrides (Muir et al. 1994). At this locality it comprises syenitic gneisses derived from juvenile mantle-derived protoliths (Marcantonio et al. 1988; Daly \& McLelland 1991; Muir et al. 1994). Muir et al. (1994) reported geochemical data for the complex that revealed a calc-alkaline composition and trace element patterns with negative Nb-and Ti-anomalies suggesting an island-arc or subduction-related environment. The Rhinns basement probably originated during the Laxfordian event at 1.9 to $1.6 \mathrm{Ga}$ and is assumed to underlay the NW Grampian Highlands as has been inferred from the $\mathrm{Nd}$ isotope compositions of Caledonian granites (Dickin \& Bowes 1991). In addition to the Rhinns component, isotope constraints of Caledonian granites indicate Grenvillian material of $c a$. 1.2 to $1.0 \mathrm{Ga}$ (Clayburn 1988). Possible subordinated components of the basement originated from the Scourian event at ca. $2.7 \mathrm{Ga}$ and the Knoydartian event at $c a .0 .8 \mathrm{Ga}$. The evidence for the Scourian event has been inferred from the Nd model ages of the Corrieyairack granite (Clayburn 1988). Some of the tectonic deformation within the Grampian Highlands has been attributed to the Knoydartian event (Friend et al. 1997; Rogers et al. 1998; Vance et al. 1998; Oliver et al. 2000). Evidence for related regional metamorphism is given by U-Pb titanite ages in the Western Highlands (Tanner \& Evans 2003).

Dalradian metasedimentary rocks cover most of the Grampian Highlands and are made up of Archean and Proterozoic detritus (Cawood et al. 2003) deposited at the passive margin of Laurentia in the Late Proterozoic and Early Phanerozoic. Contemporaneously with the Dalradian sedimentation, the $c a$. 600 Ma rifting-related Tayvallich volcanic rocks and a series of small granitic intrusions were emplaced (e.g. Anderton 1985; Halliday et al. 1989; Tanner 1996; Dempster et al. 2002). These granitoids belong, among others, to the "Older Granites" of Read (1961) and were interpreted as S-type granitoids due to their high initial Sr isotope ratios (see review of Stephenson \& Gould 1995).

The syn- to late-tectonic stages of the Grampian Orogeny involved the collision of the Midland Valley island arc with the Grampian terrane from ca. 470 to 450 Ma (Stephenson \& Gould 1995, Hutchinson \& Oliver 1998, Oliver 2001). Arc collision was accompanied by emplacement of granitic rocks and subordinate mafic to ultramafic intrusions (e.g., the ca. 470 Ma "Newer Gabbros"; Dempster et al. 2002). Among the late-tectonic granitoids two types may be distinguished: (1) Biotite-muscovite-bearing granites and granodiorites with S-type characteristics and high initial Sr isotope ratios (Pankhurst 1974; Pidgeon \& Aftalion 1978), and (2) granodiorites with I-type characteristics and subordinate diorites (e.g. Harrison 1987; Gould 1997). The origin of these granitoids has been explained by decompression melting of lower crust following post-orogenic uplift (Oliver 2003).

During the post-tectonic stage of the Grampian Orogeny plate subduction took place under Laurentia, i.e. the Scandian phase, due to the ongoing continental convergence. Asscociated magmatism lasted from $c a .430$ to 395 Ma and it is characterized by the emplacement of voluminous intermediate to felsic igneous rocks, i.e. the "Newer Granites" of Read (1961). They are undeformed, show I-type affinity, and maybe subdivided into three suites (e.g. Stephens \& Halliday 1984; Halliday 1984; Halliday et al. 1985; Plant 1986): 1) The southern Grampian Highland Suite with small intrusions of dioritic to granitic composition and mafic dykes, 2) the Argyll Suite including tonalites and granites with unusually high Ba und Sr concentrations, and 3) the Cairngorm Suite with highly differentiated biotite-bearing granites of transitional I- to A-type composition. The predominantly calc-alkaline composition of the post-tectonic granitoids has been interpreted as evidence for an active Andean- 
type plate margin setting of the Grampian terrane after the Midland Valley island arc was accreted (Dewey 1971; van Breemen \& Bluck 1981; Soper 1986; Thirlwall 1988; Oliver 2001). The final voluminous granite magmatism following docking of Avalonia has raised much speculation regarding the underlying geodynamic causes (e.g. Bluck 2001; Oliver 2001). It has been discussed in the context of an oblique collision of Avalonia and Baltica with Laurentia at ca. $435 \mathrm{Ma}$ and accretion of Armorica at ca. $410 \mathrm{Ma}$ (Soper \& Hutton 1984; Oliver 2003). Atherton \& Ghani (2002) were the first to explain the final magmatism by slab break-off during the latestage of subduction. Recent publications by Oliver (2003) and Oliver et al. (2008) have refined the slab break-off model for the British Caledonides.

The Caledonian granites show mainly S- and I-type characteristics. This classical division was originally established for the granitoid suite of the Lachlan Fold Belt in SE Australia by Chappell \& White (1974) and has been applied to granite suites all over the world. S-types are peraluminous and derived from sedimentary protoliths whereas I-types are peraluminous to metaluminous and extracted from igneous protoliths. Typically, S-types exhibit higher initial Sr isotope ratios and higher $\mathrm{K}, \mathrm{Rb}$, and $\mathrm{Pb}$ but lower $\mathrm{Na}$, $\mathrm{Ca}$, and $\mathrm{Sr}$ contents when compared to I-types (Chappell \& White 1992). Further recognized varieties within the Caledonian suite are Atype granites. A-type granites are interpreted as of anorogenic origin and characterized by high $\mathrm{SiO}_{2}, \mathrm{Fe} / \mathrm{Mg}$, $\mathrm{Ga} / \mathrm{Al}, \mathrm{Zr}, \mathrm{Nb}, \mathrm{Ga}, \mathrm{Y}$ and Ce, and low Ca and Sr (e.g. Whalen et al. 1987). However highly fractionated I- and Stype granites may exhibit similar chemical features (Whalen et al. 1987). Many of the Caledonian granitoids show transitional compositions of S- and I-type or I-and A-type underlining the difficulty to unravel their petrogenesis with geochemical discrimination diagrams.

\section{Samples and analytical methods}

For the purpose of constraining source evolution and possible tectonic settings of the granitoid and related rocks, twenty-five samples thought to be representative of the Caledonian Orogeny were analyzed. Samples assigned in this study to the "collision stage" are those referred to by Stephenson \& Gould (1995) as belonging to the synand late-tectonic stages. They characterize the main tectonic event namely the collision of the Midland Valley arc with the Grampian Highlands. The subsequent stage with Andean-type magmatism is referred to the "subduction stage" and includes those attributed to the post-tectonic stage by Stephenson \& Gould (1995). A brief petrographic sample description, available ages including new zircon ages determined by SHRIMP (Oliver et al. 2008), and sample localities are listed in Table 1. The sampled intrusions are indicated in Fig. 1b. The zircons data of Oliver et al. (2008) were used to establish the chronology of the emplacement of the samples and calculate initial $\varepsilon_{\mathrm{Nd}}$ values. Some intrusions yielded little precise zircon ages due to open system behaviour of the U-Pb system during Barrovian metamorphism at $470 \mathrm{Ma}$ (Sm-Nd garnet age; Oliver et al. 2000). For example the discordant U-Pb zircon data of RC-15 (Rough Craig) yielded only a little precise intercept age of $511 \pm 37$ Ma. For the Dunfallandy Hill intrusion (samples DH-1 and DH-2) we assume a similar age as for the Rough Craig intrusion (sample RC-15) as they are isotopically and geochemically similar and the Rb-Sr whole-rock isochron age of $481 \pm 15$ Ma for the Dunfullandy Hill intrusion (Pankhurst \& Pidgeon 1976) overlaps within errors with that of RC-15.

Fresh rock chips were ground in a tungsten carbide mill. The major- and some trace-element concentrations were analyzed by XRF at the University of St. Andrews, Scotland. Analytical details are described in Stephens and Calder (2004). Repeated analyses of sample GK-3 $(\mathrm{N}=10)$ yielded an external precision of $\pm 5 \%$ (2 s.d.) for most major- and the reported trace-elements. La, Ce, Nd, and Th at very low concentration levels $(<20 \mathrm{ppm})$ yielded a precision of up to $\pm 30 \%$. The accuracy is better than $\pm 5 \%$ (2 s.d.) for most major- and trace-element concentrations as has been determined with 20 major-element analyses of the granite rock standard GA and 6 trace-elements analyses of the granite rock standard AC-E.

After evaluation of the XRF-data set, a subset of fourteen samples was selected for ICP-MS trace element analysis and Sm-Nd isotope measurements. Trace-element analysis by inductively coupled plasma mass spectrometry (ICP-MS) was performed at the Geoforschungszentrum Potsdam, Germany, and followed the procedures of Dulski (2001). The sample powders were dissolved under pressure by a mixture of $\mathrm{HF}$ and $\mathrm{HClO}_{4}$ using an acid digestion system (Pico Trace, Germany).The external precision is better than $\pm 5 \%$ ( 2 s.d.) and the accuracy is better than $\pm 6 \%$ ( 2 s.d.) as determined on well known international reference materials (Dulski 2001).

The Sm and Nd isotope ratios were determined at the University of Munich, Germany, using a Finnigan MAT 261 thermal ionization mass spectrometer (TIMS) and a dynamic quadruple mass collection routine for $\mathrm{Nd}$ and a single cup routine for Sm. The chemical procedures are outlined in Hegner et al. (1995). The ${ }^{143} \mathrm{Nd} /{ }^{144} \mathrm{Nd}$ ratios are normalized to ${ }^{146} \mathrm{Nd} /{ }^{144} \mathrm{Nd}=0.7219$. Measurements of an Ames-metal $\mathrm{Nd}$ solution prepared at Munich yielded a ${ }^{143} \mathrm{Nd} /{ }^{144} \mathrm{Nd}$ ratio of $0.512141 \pm 13$ (2 $\sigma$ of 30 measurements) corresponding to 0.511853 in the La Jolla Nd standard. The ${ }^{147} \mathrm{Sm} /{ }^{144} \mathrm{Nd}$ ratios are precise to $0.2 \%(2 \sigma)$ as verified on the Caltech reference solution (Wasserburg et al., 1981). The external precision of the initial $\varepsilon_{\mathrm{Nd}}$ values is $\pm 0.3 \varepsilon_{\mathrm{Nd}}$ units $(2 \sigma)$. The $\mathrm{Nd}$ and Sm concentrations determined by isotope dilution and ICP-MS agree for most samples to within 5\%. Larger deviations in some samples are probably due to heterogeneous sample powders. 


\section{Results}

\section{Major- and trace-element data}

The $\mathrm{SiO}_{2}$ concentrations in the granitoid samples of the different tectonic stages range from 64 to 78 wt.\% and classify them as granodiorite to high-silica granite (Table 2). In the Streckeisen diagram using CIPW normative mineral compositions (Fig. 2), collision-related rocks are classified as granites, whereas subduction-related rocks reveal a wide compositional spectrum including monzodiorites, granodiorites, granites and alkali granites. All granitoid samples have a high- $\mathrm{K}$ calc-alkaline affinity as suggested by the $\mathrm{K}_{2} \mathrm{O}$ versus $\mathrm{SiO}_{2}$ diagram of Rickwood (1989; not shown). When considering the Al, Na, K, and Ca concentrations (Shand's Index), the samples of the different tectonic stages reveal overall peraluminous compositions although at different levels (Fig. 3). The collision-related granitoids characterized by high $\mathrm{SiO}_{2}$ concentrations of 70 to 74 wt.\% have a distinct peraluminous composition as indicated by an A/CNK ratio (molar $\mathrm{Al}_{2} \mathrm{O}_{3} /\left(\mathrm{CaO}+\mathrm{Na}_{2} \mathrm{O}+\mathrm{K}_{2} \mathrm{O}\right)$ of $1.1-$ 1.3 (Clarke 1981)). This finding indicates a strong affinity to S-type granitoids. The subduction-related granitoids exhibit variable $\mathrm{SiO}_{2}$ concentrations of 68 to $78 \mathrm{wt} . \%$ and they have peraluminous to slightly metaluminous composition $(\mathrm{A} / \mathrm{CNK}=0.8-1.2)$. This group of samples comprises transitional S- to I-type granitoids.

The trace-element patterns in Fig. 4 show the typical characteristics of granitoid rocks such as a strong enrichment in incompatible elements coupled with negative anomalies of $\mathrm{Nb}$ and $\mathrm{Ti}$ and positive $\mathrm{Pb}$-anomalies. In many samples there are joined negative anomalies of $\mathrm{Eu}$ and $\mathrm{Sr}$. In the following we will describe in brief the trace-element characteristics of the samples. Of the four samples of the collision stage (DH-2, RC-15, GK-3, M4, Figs. 4a-d) the older samples DH-2 and RC-15 (Figs. 4a, b) display steeper REE patterns $\left(\mathrm{La} / \mathrm{Yb}_{\mathrm{N}}=25\right.$ and 13 , respectively) than in the younger ones coupled with very small negative $\mathrm{Eu}$ - and $\mathrm{Nb}$-anomalies. The younger samples GK-3 and M-4 (Figs. 4c, d) tend to have higher REE concentrations and less fractionated REE patterns $\left(\mathrm{La} / \mathrm{Yb} \mathrm{b}_{\mathrm{N}}\right.$ ratios $=6$ and 13, respectively) than the older samples and they show little to unfractionated heavy REE (HREE) patterns. They have small positive Eu- and Sr-anomalies and contrasting the older samples, distinctly negative Nb-anomalies.

The granitoids of the subduction stage depict a wide spectrum of trace-element patterns (Figs. 4e-l) and may be grouped into three types. Samples MC-5, GG-12, and GD-16 (Figs. 4g, h) show subparallel REE patterns with moderately fractionated HREE patterns $\left(\mathrm{La} / \mathrm{Yb}_{\mathrm{N}}=10\right.$ to 24). The samples show minor negative Eu-anomalies and small anomalies for Pb and Ti. Samples P-22, P-27, LL-9, B-13, MB-19 (Figs. 4e, f, i, j) are characterized by little fractionated $\mathrm{REE}$ patterns $\left(\mathrm{La} / \mathrm{Yb} \mathrm{b}_{\mathrm{N}}\right.$ ratios $=9$ to 14$)$ and distinct negative Eu- and $\mathrm{Sr}$-anomalies. Remarkable is the enrichment in $\mathrm{Pb}$ and Th in these samples. A third type of pattern is confined to the dykes GG-11 and P-25 (Figs. 4k, l). The samples show an enrichment of HREE over light REE (LREE) (La/ $/ \mathrm{Yb}_{\mathrm{N}}$ ratios $=0.3$ and 1.0, respectively) with tetrad-type features (Bau, 1996) such as of convex patterns for four element groups (La-Nd, Nd-Gd, Gd-Er, Er-Lu). In addition there are very large negative anomalies of $\mathrm{Ba}$, Eu, Sr, and Ti and significant enrichments of Th and $\mathrm{Pb}$.

\section{Sm - Nd isotope systematics}

The Nd isotope data listed in Table 3 and depicted in Fig. 5 show a temporal variation with systematically increasing initial $\varepsilon_{\mathrm{Nd}}$ values through time and ongoing orogeny. Samples of the collision stage exhibit low initial $\varepsilon_{\mathrm{Nd}}$ values of -14.1 to -11.2 corresponding to mean crustal residence ages (Arndt \& Goldstein, 1987) of 2.3 to 2.0 Ga. The granitoids produced during the subduction stage show much higher initial $\varepsilon_{\mathrm{Nd}}$ values of -6.9 to -2.1 (Nd model ages 1.6 to $1.2 \mathrm{Ga}$ ) than those formed earlier. Published Nd isotope data of Clayburn (1988), Frost and O'Nions (1985), Halliday (1984), and Hamilton et al. (1980) recalculated for new SHRIMP zircon ages of Oliver et al. (2008) plot on the data trend of samples of this study (Table 3 and Fig. 5) and provide additional support for the source evolution of the granitoids.

\section{Discussion}

Temporal variation in source compositions and petrogenetic processes

A changing source composition from the arc-continent collision to the subduction stage is reflected in increasing $\varepsilon_{\mathrm{Nd}}$ values and a change from distinctly peraluminous to transitional peraluminous-metaluminous compositions of the granitoids. Noteworthy is the high abundance of felsic intrusive rocks and the lack of intermediate compositions suggesting that crystal fractionation of mafic parental magmas was not important but instead partial melting of crustal sources in the course of underplating of crust by basaltic magmas or crustal delamination. In the following we will explore the nature of the sources and petrogenetic processes for changing granitoid compositions through time.

Collision-related granitoids. The granitoids of 511 to 451 Ma that intruded the Grampian basement during collision of the Midland Valley arc with the Grampian terrane have a distinct peraluminous S-type composition 
and exhibit very low initial $\varepsilon_{\mathrm{Nd}}$ values of -14.1 to -11.2 corresponding to old $\mathrm{Nd}$ model ages of 2.3 to $2.0 \mathrm{Ga}$ (Fig. 5, Table 2). All these characteristics are consistent with melting of large amounts of old sedimentary protoliths. The $\varepsilon_{\mathrm{Nd}}$ values of possible Dalradian metasedimentary sources reported in the literature are highly variable from $c a$. -7 to -22 at 500 Ma (average about -14, corresponding to a Nd model age of $2.3 \mathrm{Ga}$; O’Nions et al. 1983; Frost \& O’Nions, 1985; recalculated for $500 \mathrm{Ma}$ ). Similarly low values in the granitoids of the collision stage requires large-scale homogenisation of the variety of lithologies or isotopically similar protholiths within the Dalradian rocks. In Fig. 5 it can be seen that the samples of the collision stage overlap the isotope evolution of the Rhinns, the Dalradian, as well as Grenvillian rocks. This coincidence shows that the Nd isotope data alone cannot constrain possible source rocks. However, involvement of Dalradian metasediments is supported by field evidence from the NE Grampian Highlands showing migmatites with sill-like granitic bodies and granites with rafts of metasedimentary rocks of/or gradational contacts to Dalradian country rock (Johnson et al. 2001; Johnson et al. 2003; Stephenson \& Gould 1995).

The REE patterns of samples RC-15 and DH-2 reveal subordinate negative Eu-anomalies indicating little plagioclase control during magma evolution and fractionated HREE patterns are consistent with partial melting of garnet-bearing sedimentary rocks, probably greywackes (McMillan et al., 2003).

Magma evolution by fractional crystallization from a mafic parental magma would have resulted in prominent negative Eu-anomalies (Gromet \& Silver 1987) in these rocks and can be ruled out. The unusually low total REE abundances suggest a source that underwent previous melting and possibly consumption of plagioclase. RC-15 and DH-2 have within-error limits similar ages and geochemical-isotopic characteristics suggesting a comagmatic relationship. It can be seen that sample RC-15 with $c a$. $73 \% \mathrm{SiO}_{2}$ has a factor of two higher-REE abundances than the little more fractionated sample $\mathrm{DH}-2$ with $c a$. $74 \% \mathrm{SiO}_{2}$. If both samples were produced as separate magma batches by melting of a similar source, as required by $\mathrm{Nd}$ isotopes, the much higher REE abundances in sample RC-15 would require a much a smaller degree of source melting than for DH-2. However, the similar $\mathrm{K}_{2} \mathrm{O}$ concentrations in both samples preclude large differences in the melting degrees for these samples and we need to explain the relationship of these samples and their different REE abundances by fractionation of accessory phases, rich in REE. This cannot be achieved with major rock-forming silicates as they have low partition coefficients for the REE and their fractionation cannot explain the low REE abundances in DH-2 (e.g. Henderson, 1984). The very low $\mathrm{P}_{2} \mathrm{O}_{5}$-concentration in $\mathrm{DH}-2$ suggest fractionation of P-bearing phases such as apatite and monazite both having very high REE concentrations and its low Ti concentrations may be due to involvement of sphene (e.g. Henderson, 1984). Their removal from a magma with the composition of RC-15 would drastically lower the REE abundances. As the REE pattern in apatite is only slightly convex with highest enrichment of the middle REE its fractionation is potentially suited to lower the overall REE abundances in the evolved melt as required for sample DH-2. This would also explain the smaller negative Eu-anomaly in DH-2 than in RC-15 as apatite discriminates against Eu. A higher Gd/Yb ratio in DH-2 is consistent with an origin by apatite fractionation from a parental magma such as RC-15, but a lower La/Sm ratio is the opposite of what would be expected. We suggest additional fractionation of highly LREE-enriched allanite and/or monazite which would decrease the $\mathrm{La} / \mathrm{Sm}$ in the evolved magma. The unusual small $\mathrm{Nb}$ anomaly of RC-15 and DH-2 appears to be inherited from the source as trace-element pattern of Dalradian metapelitic rocks exhibit likewise very small negative Nb anomalies (Johnson et al. 2003; Dalrymple 1995).

Applying the same line of reasoning to younger granitoids GK-3 and M-4, differing mainly in their contents of LREE at similar HREE, we suggest a comagmatic origin and fractionation of LREE-enriched monazite to account for the lower LREE abundances in the chemically more evolved sample GK-3. Both samples show slightly positive Eu-anomalies indicating presence of cumulate plagioclase in particular in sample GK-3. Noteworthy are the little fractionated HREE patterns consistent with melting of garnet-free sources.

Subduction-related granitoids. Granitoids of 425 to 406 Ma, i.e. those intruded after the Midland Valley arccontinent collision, were interpreted as related to plate subduction along an Andean-type plate margin and represent the final igneous event of the Caledonian Orogeny in Scotland (e.g. Dewey 1971; Soper 1986; Oliver et al. 2008). These granitoid samples yielded much higher initial $\varepsilon_{\mathrm{Nd}}$ values of -6.9 to -2.1 and relatively young Nd model ages of 1.6 to 1.2 Ga when compared with the collision stage samples (Fig. 5, Table 2). Their sources show clearly involvement of significant amounts of juvenile mantle-derived material. A very wide range of rock types ranging from granodiorites to alkali granites with I-type and S-type characteristics were produced during this event. Alkali granites are associated with crustal rifting (e.g. Lee et al. 2003) supporting that the magmatic arc possibly underwent extension (Soper \& Hutton 1984; Oliver 2003; Dewey \& Strachan 2003; Oliver et al. 2008). It is noteworthy that highly evolved granitoids dominate the rock spectrum in the subduction stage. Intermediate andesitic compositions are evidently missing and this finding suggests melting of mostly crustal protoliths as would be expected in regions of thick crust heated from below by underplating of basalt or input of heat from rising asthenosphere after delamination of lower crust. Development of a lower and middle crust with mixing, crustal assimilation, storage, and hybridization of melts (MASH) as originally proposed by Hildreth \& Moorbath (1988) and refined by Annen et al. (2006) for Andean-type margins may serve as a model. During plate subduction below Laurentia mantle-derived melts probably underplated and assimilated older crust of 
possibly Laxfordian and Grenvillian origin. The mixing of residual melts from basalt crystallization and crustal partial melts of metasedimentary and metaigneous rocks can lead to diverse signatures in isotope and traceelement chemistry (Annen et al., 2006). The Nd isotope signature of the subduction-related granititoids indicates variable mixing of different sources, whereas the trace-element chemistry is mainly controlled by fractionation processes. The range in initial $\varepsilon_{\mathrm{Nd}}$ values of -2 to -8 of the subduction-related granitoids suggests a heterogeneous lower basement of the Grampian terrane, which is probably of Laxfordian and Grenvillian origin and has been rejuvenated during the Caledonian orogenic cycle. Assimilation of Dalradian metasediments during magma ascending may contribute to low initial $\varepsilon_{\mathrm{Nd}}$ values. Mantle-derived and associated Lorne lavas yielded initial $\varepsilon_{\mathrm{Nd}}$ values of up to 1.2 (Thirlwall 1982).

The arc-like REE patterns in 420 to 415 Ma samples (e.g. GD-16, MC-5, GG-12) strongly suggest plate subduction and melting of mantle and lower crustal sources for these samples. This interpretation is at odds with the geodynamic model of Oliver et al. (2008) who argued for ceasing of plate subduction at $420 \mathrm{Ma}$, followed by calc-alkaline magmatism in extensional basins during slab-roll back. The samples are similar to the "high Ba-Sr" granites of the Argyll Suite described by Stephens and Halliday (1984). The 420-415 Ma samples are metaluminous in composition indicating a high proportion of igneous material in their sources. The protoliths also contain in some cases large amounts of mantle-derived material as indicated by initial $\varepsilon_{\mathrm{Nd}}$ values of up to 2.1 (Fig. 5, Table 2). The LREE-enriched patterns show only minor negative Eu-anomalies typical of many subduction-related magmas from mature island arcs or active continental margin (e.g. Gromet \& Silver 1987). The magmas must have erupted rapidly from the lower crust without ponding in shallow-level magma chambers with major plagioclase fractionation (Gromet \& Silver 1987). The high Sr and Ba concentrations in these rocks further reflect the subordinate role of feldspar and large contributions of slab-derived fluids, respectively (summary of references in Morris \& Ryan 2004). These features together with unfractionated HREE patterns suggesting limited melt fractionation of mantle-derived magmas outside the garnet-stability field (Fowler and Henney 1996; Fowler et al. 2001). Of the 420 to 415 Ma old rock suite, sample GD-16 is of basaltic-andesite composition (MgO 4.2 wt.\%) and represents a typical mantle-derived melt from subduction-modified mantle. Its low initial $\varepsilon_{\mathrm{Nd}}$ value of -5.9 indicates a large proportion of older crustal material inherited from assimilation of lower crust. The granodiorites MC-5 (420 Ma) and GG-12 (415 Ma, Fig. 4d) have similar REE patterns but much higher initial $\varepsilon_{\mathrm{Nd}}$ value of -3 to -2 indicating different sources than that of mafic granitoid GD-16. The origin of granodiorite (e.g. samples MC-5 and GG-12) in subduction zone has been discussed in the context of magma fractionation from basaltic parental magmas and partial melting of mafic protoliths (see discussion in Gromet \& Silver 1987). The lack of intermediate rock compositions and distinct negative Eu anomalies in the granodiorite samples do not support magma fractionation as the primary process for their development. Instead we suggest in addition to mantle melting, partial melting of mafic lower crust during magma storage in the lower crust (e.g. Rapp \& Watson 1995).

Another group of subduction-related granitoids comprises high-silica alkali granites of the Peaterhead intrusion that was emplacement at $c a .425$ Ma. (e.g. P-22, P-27, Fig. 4e) shortly before the end of plate subduction according to the model of Oliver et al (2008). For these granitoids magma evolution in shallow-level magma chambers in the presence of feldspar and Ti-oxides is indicated by their large negative Eu-, Sr- and Ti-anomalies, respectively. For these samples we suggest a two-stage magma evolution by partial melting of mafic lower crust followed by magma fractionation at higher crustal levels. Initial $\varepsilon_{\mathrm{Nd}}$ values of - 4 to -7 indicate involvement of large proportions of older crust.

Besides the more typical subduction-related rocks highly fractionated alkali granite dykes as can be found in the Glen Gairn and Peterhead intrusions (samples GG-11, P-25) were emplaced during final plate subduction. These samples show very distinct and similar geochemical and isotopic characteristics so that we assume them to be of similar age and comagmatic origin. Both ages that we cite have not been published so that the definite age of these samples may be $415 \mathrm{Ma}$ as suggested by U-Pb zircon dating (Parry, pers. com.) or $425 \mathrm{Ma}$ (Torsvik, pers. com.). The age difference is not important here for deciphering their petrogenesis. The evolved major-element composition and remarkable depletion in $\mathrm{P}_{2} \mathrm{O}_{5}$ and LREE may be due to fractionation of monazite, allanite and apatite. Low $\mathrm{Ba}, \mathrm{Sr}, \mathrm{Eu}$, and Ti contents can be explained by extensive magma fractionation of feldspar, and $\mathrm{Fe}-$ Ti-oxides. $\varepsilon_{\mathrm{Nd}}$ values of -6.2 and -6.4 suggest sources similar to those of the contemporaneously emplaced granitoids. The REE patterns of these samples show a slight tetrad effect that is characterized by four element groups (La-Nd, Nd-Gd, Gd-Er, Er-Lu) forming four segments of convex patterns. The tetrad effect is often accompanied by a non-charge-and-radius-controlled (non-CHARC) behaviour of other trace elements (Bau 1996) as reflected in $\mathrm{Zr} / \mathrm{Hf}$ ratios of 12 and 14, respectively that are distinct from a ratio of $37 \pm 3$ in mantle- and crust-derived igneous rocks (Bau 1996). These characteristics have been explained as due to melt fractionation processes, a major influence of apatite (McLennan 1994) and interaction of residual granitic melts with hydrothermal fluids in a highly evolved magma system (Jahn et al. 2001). Adopting the hypothesis that the felsic rocks types represent partial melts of lower crust, rather than the products of fractionation of mafic parental melts, these high-silica LREE-depleted granitoids may could represent small-volume residual melts after extensive shallow-level melt fraction. 
The $c$ a. 406 Ma old granites (s.s.; e.g. MB-19, LL-9, B-13; Fig. 4) are transitional between I and S-type and may have been generated after active subduction (Oliver et al, 2008). As mantle melting cannot have been important anymore, we interpret these typical granites as resulting from melting of lower crust similar to that involved during final plate subduction as indicated by initial $\varepsilon_{\text {Nd }}$ values of -4 to -5 . Large negative Eu-, Sr- and Tianomalies are consistent with magma evolution in shallow-level magma chambers in the presence of feldspar and Ti-oxides. The geochemical similarity and the small range in initial $\varepsilon_{\mathrm{Nd}}$ values these granites indicate very similar sources and petrogenetic processes. Interesting to note is that the geochemical evidence in these granites fails to identify the tectonic environment of their genesis, instead characteristics of older tectonic processes are recycled in their trace elements and isotopes.

\section{Plate tectonic development}

The Caledonian magmatism in Scotland is closely related to the tectonic evolution of the Laurentia margin and can be unravelled with the chemical and isotopic data of igneous rocks represent the different stages of orogeny. In the Neoproterozoic Laurentia rifted from West Gondwana during the break-up of the supercontinent Rodinia and the initial opening of the Iapetus Ocean. In the Ordovician collision of island arcs with Laurentia marked the beginning of the closure of the Iapetus Ocean, which resulted in the amalgamation of Laurentia, Avalonia, and Baltica. Below we discuss a possible geodynamic evolution of the Grampian terrane (Fig. 1c) that follows recently published models (Oliver 2001; Oliver 2003; Oliver et al. 2008) and integrates the new geochemical and isotope information obtained in this study. It can be seen that the geochemical data of the highly dynamic orogenic development provide a rather simple image of crustal evolution with remobilization of pre-existing crust followed by production of increasingly more rejuvenated crust.

Rifting stage. Crustal thinning and lithospheric rifting at ca. 600 Ma produced bimodal mafic-felsic magmatism consistent with melting of mantle and crustal sources during (e.g. Sears et al. 2005) (Fig. 1c, stage 1). The ca. 590 Ma Ben Vuirich A-type granite (U-Pb zircon TIMS age, Rogers et al. 1989) yielded an initial $\varepsilon_{\mathrm{Nd}}$ values of 4.9 (Hamilton et al. 1980) consistent with melting of mixed recycled-juvenile sources whereas the ca. $600 \mathrm{Ma}$ Tayvallich volcanics (Dempster 2002) with initial $\varepsilon_{\mathrm{Nd}}$ values of up to +4 (Halliday et al. 1989) reveal mostly depleted upper mantle sources. The Tayvallich volcanics are probably related to extensive mantle melting and crustal underplating during continental break-up (Anderton 1985; Kamo et al. 1989). From 585 to 470 Ma the margin of Laurentia remained passive as the Iapetus Ocean was opening (Fig. 1c, stage 2; Oliver et al. 2008).

Collision stage. There is general agreement that in the early Ordovician a continent-facing island arc collided with the Laurentia margin causing the Grampian Orogeny in Scotland (e.g. Dewey \& Shackleton 1984; Fig. 1c, stage 3). Magmatic and cooling ages constrain magmatism, deformation, high-grade regional metamorphism, and unroofing of Scotland and Ireland to a short time interval from 470 to $460 \mathrm{Ma}$ (Friedrich et al. 1999; Soper et al. 1999; Dewey \& Mange 1999; Oliver et al. 2000). Geochemical and isotope data for the collision-related granitoids indicate rather uniform, mostly metasedimentary sources probably of old Dalradian provenance. Melting of sedimentary protoliths may have been facilitated by heat supplied from mantle-derived melts forming intrusions such as the "Newer gabbros" at ca. $470 \mathrm{Ma}$ (Dempster et al. 2002). The origin of these mafic to ultramafic intrusions as well as the high-grade regional metamorphism has been explained with a number processes such as slab break-off (Oliver 2001; 2003), delamination of the lower mafic crust (Draut et al. 2002; 2004), and contact of hot asthenosphere with the Laurentia margin as the arc collided with Laurentia (Dewey \& Mange 1999). Decompression melting of Dalradian metasedimentary due to isostatic readjustment of the thickened Grampian terrane has been suggested by Oliver (2001, 2003). Evidence for decompression, uplift and erosion is provided by K-Ar cooling ages of ca. 455 Ma for mica (Dempster 1985) and the contemporaneous deposition of metamorphic detritus from the Grampian terrane in the Southern Uplands accretionary prism (Oliver et al. 2000). The data of this study corroborate a model that during the collision of the Midland Valley arc with the Grampian terrane melting of old metasedimentary rocks probably of Dalradian provenance was important. The traceelement data suggest melting of material with charateristics of garnet-bearing and garnet-free greywackes. The necessary heat may have been generated during crustal thickening and intrusion of mantle-derived melts. The lack of evidence for juvenile material in these granitoids, if representative for the collision stage, indicates that subduction zone melting below Laurentia was not important before $\sim 430 \mathrm{Ma}$ as proposed in recent models for Scotland (Oliver 2001; 2003).

Subduction stage. After the Grampian Orogeny an active Laurentia margin probably developed with subduction beneath the accreted Midland valley arc and Grampian terrane (Fig. 1c, stage 4). Zircon ages constrain the final igneous activity to 430 to 390 Ma (Oliver et al. 2008). The geochemical data presented above show a very wide compositional spectrum of mostly granitoids suggesting melting of protoliths with a high proportion of mantlederived material. The sources of the granitoids apparently were produced in a plate subduction setting. It has been argued that subduction ceased with the soft docking of Avalonia before magmatism ceased (e.g. Soper et al., 1992). This would imply that the late generation of magma resulted from post-subduction processes. This 
possibility cannot be precluded with the geochemical data presented here that show that the youngest granitoids are highly evolved granites probably derived melting of earlier rejuvenated crustal sources. Strike slip faulting due to the oblique collision of Avalonia and Baltica with Laurentia (e.g. Soper \& Hutton 1984, Dewey and Strachan 2003), slab roll-back (Oliver 2003) and/or slab break-off (Atherton \& Ghani 2002) all would ensue heating of lower crust and decompression melting. Processes such as slab roll-back and slab break-off have been proposed during the late-stage of subduction but cannot be evaluated with geochemical data as they would result in magmatic underplating and production of granitoids with similar composition as during plate subduction. The Nd isotope evidence for melting of mantle-derived material maybe taken as evidence for plate subduction until $\sim 400$ Ma but is not capable to preclude extensive lower crustal melting in a collision zone.

\section{Conclusions}

The geochemical-geochronolocial data of granitoids from the Grampian Highlands are in agreement with melting of crust and mantle during continental rifting and associated magmatic underplating at 600 Ma, arccontinent collision from $\sim 470$ to $450 \mathrm{Ma}$, and subsequent development of Andean-type plate margin. The geochemical-isotope data reveal two major igneous events that affected the crust. Granitoids produced during docking of the Midland Valley arc with Laurentia were predominantly derived by melting and recyling of older crust. Contemporaneously emplaced mantle-derived material apparently did not contribute to granite magmatism, and probably presented simply a heat source for melting of inferred Dalradian metasediments. During the final convergence of Avalonia and Laurentia melting of mixed and distinctly more juvenile sources reflect input of mantle-derived material during plate subduction. Contemporaneous emplacement of alkali granites can be explained with a rifting Andean-type plate margin as a consequence of oblique plate subduction or post-orogenic melting of collision zone assemblages.

\section{Acknowledgments}

A. Calder, carried out the XRF analyses at St. Andrews and A. Rocholl supported the analysis of Nd isotopes in Munich. We thank M. Fowler and I. Millar for their helpful and constructive reviews of the manuscript. G.S. would like to thank C. Helo for discussions.

\section{References}

Anderton, R., 1985. Sedimentation and tectonics in the Scottish Dalradian. Scottish Journal of Geology 21, 407-436.

Annen, C., Blundy, J.D., Sparks, R.S.J., 2006. The genesis of intermediate and silicic magmas in deep crustal hot zones. Journal of Petrology 47 (3), 505-539.

Arndt, N.T., Goldstein, S.L., 1987. Use and abuse of crust-formation ages. Geology 15, 893-895.

Atherton, M.P., Ghani, A.A., 2002. Slab breakoff: a model for Caledonian, Late Granite syn-collisional magmatism in the orthotectonic (metamorphic) zone of Scotland and Donegal, Ireland. Lithos 62, 65-85.

Barrow, G., 1893. On an intrusion of muscovite biotite gneiss in the southeast Highlands of Scotland and its accompanying metamorphism. Quarterly Journal of the Geological Society, London 49, 330-358.

Bau, M., 1996. Controls on the fractionation of isovalent trace elements in magmatic and aqueous systems: evidence from $\mathrm{Y} / \mathrm{Ho}, \mathrm{Zr} / \mathrm{Hf}$, and lanthanide tetrad effect. Contributions to Mineralogy and Petrology 123, 323-333.

Bluck, B.J., 2001. Caledonian and related events in Scotland. Transactions of the Royal Society of Edinburgh: Earth Sciences 91, 375-404.

Brown, G.C., 1979. Geochemical and geophysical constraints on the origin and the evolution of Caledonian granites. In: Harris, A.L., Holland, C.H., Leake, B.E. (eds.). The Caledonides of the British IslesReviewed. Geological Society, London, Special Publications 8, 645-652.

Cawood, P.A., Nemchin, A.A., Smith, M., Loewy, S., 2003. Source of the Dalradian Supergroup constrained by U-Pb dating of detrital zircon and implications of the East Laurentian margin. Journal of the Geological Society, London 160, 231-246.

Chappell, B.W., White, A.J.R., 1974. Two contrasting granite types. Pacific Geology 8, 173-174.

Chappell, B.W., White, A.J.R., 1992. I- and S-type granites in the Lachlan Fold Belt. Transactions of the Royal Society of Edinburgh: Earth Sciences 83, 1-26.

Clarke, D.B., 1981. The mineralogy of peraluminous granites. The Canadian Mineralogist 19, 3-17. 
Clayburn, J.A.P., 1981. Isotopic evidence for the age and Provenance of early, post tectonic, Caledonian intrusives in the Central Highlands of Scotland. Geophysical Journal of the Royal Astronomical Society 65 (1), 246.

Clayburn, J.A.P., 1988. The crustal evolution of Central Scotland and the nature of the lower crust: $\mathrm{Pb}, \mathrm{Nd}$ and $\mathrm{Sr}$ isotope evidence from Caledonian granites. Earth and Planetary Science Letters 90, 41-51.

Dalrymple, D.J. 1995. Contact anatexis of Dalradian metapelites from the Huntly-Knock area, Aberdeenshire, N. E. Scotland. PhD thesis, University of Manchester.

Daly, J.S., McLelland, J.M., 1991. Juvenile middle Proterozoic crust in the Adirondack Highlands, Grenville province, northeastern North America. Geology 19, 119-122.

Dempster, T.J., 1985. Uplift patterns and orogenic evolution in the Scottish Dalradian. Journal of the Geological Society, London 142, 111-128.

Dempster, T.J., Rogers, G., Tanner, P.W.G., Bluck, B.J., Muir, R.J., Redwood, S.D., Ireland, T.R., Paterson, B.A., 2002. Timing and deposition, orogenesis and glaciation within the Dalradian rocks of Scotland: constraints from U-Pb ages. Journal of the Geological Society of London 159, 83-94.

DePaolo, D.J., 1981. Neodymium isotopes in the Colorado Front range and crust-mantle evolution in the Proterozoic. Nature 291, 193-196.

Dewey, J.F., 1971. A model for the Lower Palaeozoic evolution of the southern margin of the early Caledonides of Scotland and Ireland. Scottish Journal of Geology 7, 219-240.

Dewey, J.F., Shackleton, R.J., 1984. A model for the evolution of the Grampian tract in the early Caledonides and Appalachians. Nature 312, 115-120.

Dewey, J.F, Mange, M., 1999. Petrography of Ordovician and Silurian sediments in the western Irish Caledonides: tracers of a short-lived Ordovician continent-arc collision orogeny and the evolution of the Laurentian Appalachian-Caledonian margin. In: MacNiocaill, C., Ryan, P.D. (eds.). Continental tectonics. Geological Society, London, Special Publications 164, 55-107.

Dewey, J. F., Strachan, R. A., 2003. Changing Silurian-Devonian relative plate motion in the Caledonides; sinistral transpression to sinistral transtension. Journal of the Geological Society of London 160, 219-229.

Dickin, A.P., 1998. Nd isotopic mapping of a cryptic continental suture, Grenville Province of Ontario. Precambrian Research 91, 433-444.

Dickin, A.P., 1998. Nd isotopic mapping of a cryptic continental suture, Grenville Province of Ontario. Precambrian Research 91, 433-444.

Dickin, A.P., 2000. Crustal formation in the Grenville Province: Nd-isotope evidence. Canadian Journal of Earth Sciences 37, 165-181.

Dickin, A.P., McNutt, R.H., 1989. Nd model age mapping of the southeast margin of the Archean Foreland in the Grenville Province of Ontario. Geology 17, 299-301.

Dickin, A.P., Bowes, D.R., 1991. Isotopic evidence for the extent of early Proterozoic basement in Scotland and northwest Ireland. Geological Magazine 128, 385-388.

Dickin, A.P., Higgins, M.D., 1992. Sm/Nd evidence for a major 1.5 Ga crust-formation event in the central Grenville province. Geology 20, 137-140.

Draut, A., Clift, P.D., Chew, D.M., Hannigan, R.E., Layne, G., Shimizu, N., 2002. A model for continental crust genesis by arc accretion; rare earth element evidence from the Irish Caledonides. Earth and Planetary Science Letters 203, 861-877.

Draut, A., Clift, P.D., Chew, D.M., Cooper, M.J., Taylor, R.N., Hannigan, R.E., 2004. Laurentian crustal recycling in the Ordovician Grampian Orogeny; Nd isotopic evidence from western Ireland. Geological Magazine 141, 195-207.

Dulski, P., 2001. Reference Material for Geochemical Studies: New Analytical Data by ICP-MS and Critical Discussion of Reference Values. Geostandards Newletter: The Journal of Geostandards and Geoanalysis 25, 87-125.

Flowerdew, M.J., Daly, J.S., Whitehouse, M.J., 2005. 470Ma granitoid magnetism associated with the Grampian Orogeny in the Slishwood Division, NW Ireland. Journal of the Geological Society, London 162, 563-575.

Fowler, M.B., Henney, P.J., 1996. Mixed Caledonian appinite magmas: Implications for lamprophyre fractionation and high Ba-Sr granite genesis. Contributions to Minerology and Petrology 126 (1-2), 199-215.

Fowler, M.B., Henney, P.J., Darbyshire, D.P.F., Greenwood, P.B., 2001. Petrogenesis of high Ba-Sr granites: the Rogart pluton, Sutherland. Journal of the Geological Society, London 156, 1217-1230.

Friedrich, M.A., Hodges, K.V., Bowring, S.A., Martin, M.W., 1999. Geochronological constraints on the magmatic, metamorphic and thermal evolution of the Connemara Caledonides, western Ireland. Journal of the Geological Society, London 156, 1217-1230. 
Friend, C.R.L., Kinny, P.D., Rogers, G., Strachan, R.A., $\quad$ Paterson, $\quad$ B.A., 1997. $\mathrm{U}-\mathrm{Pb}$ zircon geochronological evidence for Neoproterozoic events in the Glenfinnan Group (Moine Supergroup): the formation of the Ardgour granite gneiss, north-west Scotland. Contribution to Mineralogy and Petrology 128 (2-3), 101-113.

Frost, C.D., O'Nions, R.K., 1985. Caledonian Magma Genesis and Crustal Recycling. Journal of Petrology 26, 515-544.

Gould, D., 1997. Geology of the Country around Inverurie and Alford. Memoir of the British Geological Survey, Sheets 76W and 76E (Scotland).

Gromet, P., Silver, L.T., 1987. REE variations across the Peninsular Ranges Batholith: Implications for batholithic petrogenesis and crustal growth in magmatic arcs. Journal of Petrology, 28, 75-125.

Halliday, A.N., 1984. Coupled Sm-Nd and U-Pb systematics in late Caledonian granites and basement under northern Britain. Nature 307, 229-233.

Halliday, A.N., Stephens, W.E., Hunter, R.H., Menzies, M.A., Dickin, A.P., Hamilton, P.J., 1985. Isotopic and chemical constraints on the building of the deep Scottish lithosphere. Scottish Journal of Geology 21, 456-491.

Halliday, A.N., Graham, C.M., Aftalion, M., Dymoke, P., 1989. The depositional age of the Dalradian Supergroup: U-Pb and Sm-Nd isotopic studies of the Tayvallich Volcanics, Scotland. Journal of the Geological Society, London 146, 3-6.

Hamilton, P.J., O'Nions, R.K., Pankhurst, R.J., 1980. Isotopic evidence for the provenance of some Caledonian granites. Nature 287, 279-284.

Harmon, R.S., Halliday, A.N., Clayburn, J.A.P., Stephens, W.E. 1984. Chemical and isotope systematics of the Caledonian intrutions of Scotland in northern England: a guide to magma source regions and magma-crust interaction. Philosphical Transactions of the Royal Society, London A310, 709-742.

Harrison, T.N., 1987. The granitoids of eastern Aberdeenshire. In: Trewin, N.H., Kneller, B.C., Gillen, C. (eds.). Excursion guide to the geology of the Aberdeen area. Scottish Academic Press, Edinburgh, 243-250.

Hegner, E., Roddick, J.C., Fortier, S.M., Hulbert, L., 1995. Nd, Sr, Pb, Ar, and O isotopic systematics of Sturgeon Lake kimberlite, Saskatchewan, Canada: constraints on emplacement, alteration, and source contamination. Contribution to Mineralogy and Petrology 122, 212-222.

Henderson, P., 1984. Rare Earth Geochemistry. Developments in Geochemistry. In: Fyfe, W.S. (ed.). Developments in Geochemistry 2. Elsevier, Amsterdam, 510 pp.

Hildreth, W., Moorbath, S., 1988. Crustal contributions to arc magmatism in the Andes of central Chile. Contribution to Mineralogy and Petrology 98, 455-489.

Hutchinson, A.R., Oliver, G.J.H., 1998. Garnet provenance studies, juxtaposition of Laurentian marginal terranes and timing of the Grampian Orogeny in Scotland. Journal of the Geological Society, London 155, 541.

Jahn, B.M., Wu, F., Capdevila, R., Martineau, F., Zhao, Z.H., Wang, Y.X., 2001. Highly evolved juvenile granites with tetrad REE patterns: the Woduhe and Baerzhe granites from the Great Xing'an Mountains in NE China. Lithos 59, 171-198.

Johnson, T.E., Hudson, N.F., Droop, G.T.R., 2001. Partial melting in the Inzie Head gneisses; the role of water and a petrogenetic grid in KFMASH applicable to anatectic pelitic migmatites. Journal of Metamorphic Geology 19 (1), 99-118.

Johnson, T.E., Hudson, N.F.C., Droop, G.T.R, 2003. Evidence for the genetic granite-migmatite link in the Dalradian of NE Scotland. Journal of the Geological Society, London 160, 447-457.

Kamo, S.L., Gower, C.F., Krogh, T.E., 1989. Birthday of the Iapetus Ocean? A precise U-Pb zircon and baddeleyite age for the Long Range dikes, southeast Labrador. Geology 17, 602-605.

Kneller, B.C., Aftalion, M., 1987. The isotopic and structural age of the Aberdeen Granite. Journal of the Geological Society, London 144, 717-721.

McLennan S.M., 1994. Rare earth element geochemistry and the "tetrad effect. Geochimica et Cosmochimica Acta 58 (9), 2025-2033.

McMillan, A., Harris, N.B.W., Holness, M., Ashwal, L., Kelley, S., Rambeloson, R., 2003. A granitegabbro complex from Madagascar: constraints on melting of the lower crust. Contribution to Mineralogy and Petrology 145, 585-599.

Morris, J.D., Ryan, J.G., 1984. Subduction zone processes and implications for changing composition of the upper and lower mantle. In: Carlson, R.W. (ed). The Mantle and Core Vol. 2. Holland, H.D., Turekian, K.K. (eds.). Elsevier-Pergamon, Oxford, 451-470.

Lee, S.R., Cho, M., Cheong, C.S., Kim, H., Wingate, M.T.D., 2003. Age, geochemistry, and tectonic significance of Neoproterozoic alkaline granitoids in the northwestern margin of the Gyeonggi massif, South Korea. Precambrian Research 122 (1-2), 297-310. 
LeMaitre, R.W., 2002. Igneous rocks - a classification and glossary of terms. Cambridge University Press, Cambridge, U.K.

Liew, T.C., Hofmann, A.W., 1988. Precambrian crustal components, plutonic associations, plate environment of the Hercynian fold belt of central Europe: indications from a $\mathrm{Nd}$ and $\mathrm{Sr}$ isotopic study. Contributions to Mineralogy and Petrology 98, 129-138.

Marcantonio, F., Dickin, A.P., McNutt, R.H., Heaman, L.M., 1988. A 1800-million-year-old Proterozoic gneiss terrane in Islay with implications for the crustal structure and evolution of Britain. Nature 335, 62-64.

McDonough, W.F., Sun, S.S., 1995. The composition of the earth chemical evolution of the mantle. Chemical Geology 120, 223-253.

Muir, R.J., Fitches, W.R., Maltman, A.J., 1994. The Rhinns Complex: Proterozoic basement on Islay and Colonsay, Inner Hebrides, Scotland, and on Inishtrahull, NW Ireland. Transactions of the Royal Society of Edinburgh: Earth Sciences 85, 77-90.

Oliver, G.J.H, Chen, F., Buchwaldt, R., Hegner, E., 2000. Fast tectonometamorphism and exhumation in the type area of the Barrovian and Buchan zones. Geology 28, 459-462.

Oliver, G.J.H., 2001. Reconstruction of the Grampian episode in Scotland: its place in the Caledonian Orogeny. Tectonophysics 332, 23-49.

Oliver, G.J.H., 2003. Chronology and terrane assemblage, new and old controversies. In: Trewin, N.H. (ed.). The Geology of Scotland (4th edition). Geological Society of London, 201-211.

Oliver, G.J.H., Wilde, S.A., Wan, Y., 2008. Geochronology and geodynamics of Scottish granitoids from the late Neoproterozoic break-up of Rodinia to Palaeozoic collision. Journal of the Geological Society, London, 165, 661-674.

O’Nions, R.K., Hamilton, P.J., Hooker, P.J., 1983. A Nd isotope investigation of sediments related to crustal development in the British Isles. Earth and Planetary Science Letters 63, 229-240.

Pankhurst, R.J., 1974. Rb-Sr Whole-Rock Chronology of Caledonian Events in Northeast Scotland. Geological Society of America Bulletin 85, 345-350.

Pankhurst, R.J., Pidgeon, R.T., 1976. Inherited isotope systems in the source region pre-history of early Caledonian granites in the Dalradian Series of Scotland. Earth and Planetary Science Letters 31, 5568.

Pidgeon, R.T., Aftalion, M., 1978. Cogenetic and inherited zircon U-Pb systems in granites: Palaeozoic granites of Scotland and England. In: Bowes, D.R., Leake, B.E. (eds.). Crustal Evolution in Northwestern Britain and Adjacent Regions. Geological Journal, Special Issue 10, 183-220.

Plant, J.A., 1986. Models for granites and their mineralising systems in the British and Irish Caledonides. In: Andrew, C.J. (ed.). Geology and Genesis of Mineral Deposits in Ireland. Irish Association for Economic Geology, Dublin, 121-156.

Rapp, R.P., Watson, E.B., 1995. Dehydration melting of metabasalt at 8-32 kbar: Implications for continental growth and crystal recycling. Journal of Petrology 36, 891-931.

Read, H.H., 1961. Aspects of Caledonian magmatism in Scotland. Proceedings of the Liverpool and Manchester Geological Society 2, 653-683.

Rogers, G., Hyslop, E.K., Strachan, R.A., Peterson, B.A., Holdsworth, R.E., 1998. The structural setting and $\mathrm{U}-\mathrm{Pb}$ geochronology of Knoydartian pegmatites in $\mathrm{W}$ Inverness-shire; evidence for Neoproterozoic tectonothermal events in the Moine of NW Scotland. Journal of the Geological Society, London 155, 685-696.

Rogers, G., Dempster, T.J., Bluck, B.J., Tanner, P.W.G., 1989. A high-precision age for the Ben Vuirich granite: implications for the evolution of the Dalradian Supergroup. Journal of the Geological Society, London 146, 789-798.

Rickwood, P.C., 1989. Boundary lines within petrologic diagrams, which use oxides of major and minor elements. Lithos 22, 247-263.

Sears, J.W., St George, G.M., Winne, J.C., 2005. Continental rift systems and anorogenic magmatism. Lithos 80 (1-4), 147-154.

Soper, N.J., 1986. The Newer Granite problem: a geotectonic view. Geological Magazine 123, 227-236.

Soper, N.J., Ryan, P.D., Dewey, J.F., 1999. Age of the Grampian Orogeny in Scotland and Ireland. Journal of the Geological Society, London 156, 1231-1236.

Soper, N.J., Strachan, R.A., Holdsworth, R.E., Gayer, R.A., Greiling, R.O., 1992. Sinistral transpression and the Silurian closure of the Iapetus. Journal of the Geological Society, London 149, 871-880.

Soper, N.J., Hutton, D.H.W., 1984. Late Caledonian sinistral displacements in Britain: Implications for a three-plate model. Tectonics 3, 781-794.

Stephens, W.E., Calder A., 2004. Analysis of non-organic elements in plant foliage using polarised X-ray fluorescence spectrometry. Analytical Chimica Acta 527 (1), 89-96. 
Stephens, W.E., Halliday, A.N., 1984. Geochemical contrasts between late Caledonian granitoid plutons of northern, central and southern Scotland. Transactions of the Royal Society of Edinburgh: Earth Sciences 75, 259-273.

Stephenson, D., Gould, D., 1995. The Grampian Highlands. British Regional Geology, British Geological Survey, HMSO London, 115-148.

Strachan, R.A., Smith, M., Harris, A.L., Fettes, D.J., 2003. The Northern Highland and Grampian terranes. In: Trewin, N.H. (ed.). The Geology of Scotland (4th edition). Geological Society, London, 81-147.

Streckeisen, A.L., 1976. To each plutonic rock its proper name. Earth Science Review 12, 1-33.

Tanner, P.W.G., 1996. Significance of the early fabric in the contact metamorphic aureole of the $590 \mathrm{Ma}$ Ben Vuirich Granite, Perthshire, Scotland. Geological Magazine 133, 683-695.

Tanner, P.W.G., Evans, J.A., 2003. Late Precambrian U-Pb titanite age for peak regional metamorphism and deformation (Knoydartian orogeny) in the western Moine, Scotland. Journal of the Geological Society, London 160, 555-564.

Thirlwall, M.F., 1982. Systematic variation in chemistry and Nd-Sr isotopes across a Caledonian calcalkaline volcanic arc: implications for source materials. Earth and Planetary Science Letters 58, 2750 .

Thirlwall, M.F. 1988. Geochronology of the Late Caledonian magmatism in northern Britain. Journal of the Geological Society, London 145, 951-967.

van Breemen, O., Bluck, B.J., 1981. Episodic granite plutonism in the Scottish Caledonides. Nature 291, 113-117.

Vance, D., Strachen, R.A. Jones, K.A., 1998. Extensional versus compressional settings for metamorphism: garnet chronometry and pressure-temperature-time histories in the Moine Supergroup, northwest Highlands. Geology 26, 927-930.

Whalen, B.J., Currie, K.L., Chappell, B.W., 1987. A-type granites: geochemical characteristics, discrimination and petrogenesis. Contributions to Mineralogy and Petrology 95, 407-419.

Wasserburg, G.J., Jacobsen, S.B., DePaolo, D.J., McCulloch, M.T., 1981. Precise determination of Sm/Nd ratios, Sm and Nd isotopic abundances in standard solutions. Geochimica et Cosmochimica Acta 45, 2311-2323.

Zen, E., 1986. Aluminium enrichment in silicate melts by fractional crystallization: some mineralogic and petrographic constraints. Journal of Petrology 27, 1095-1117. 


\section{Figures}

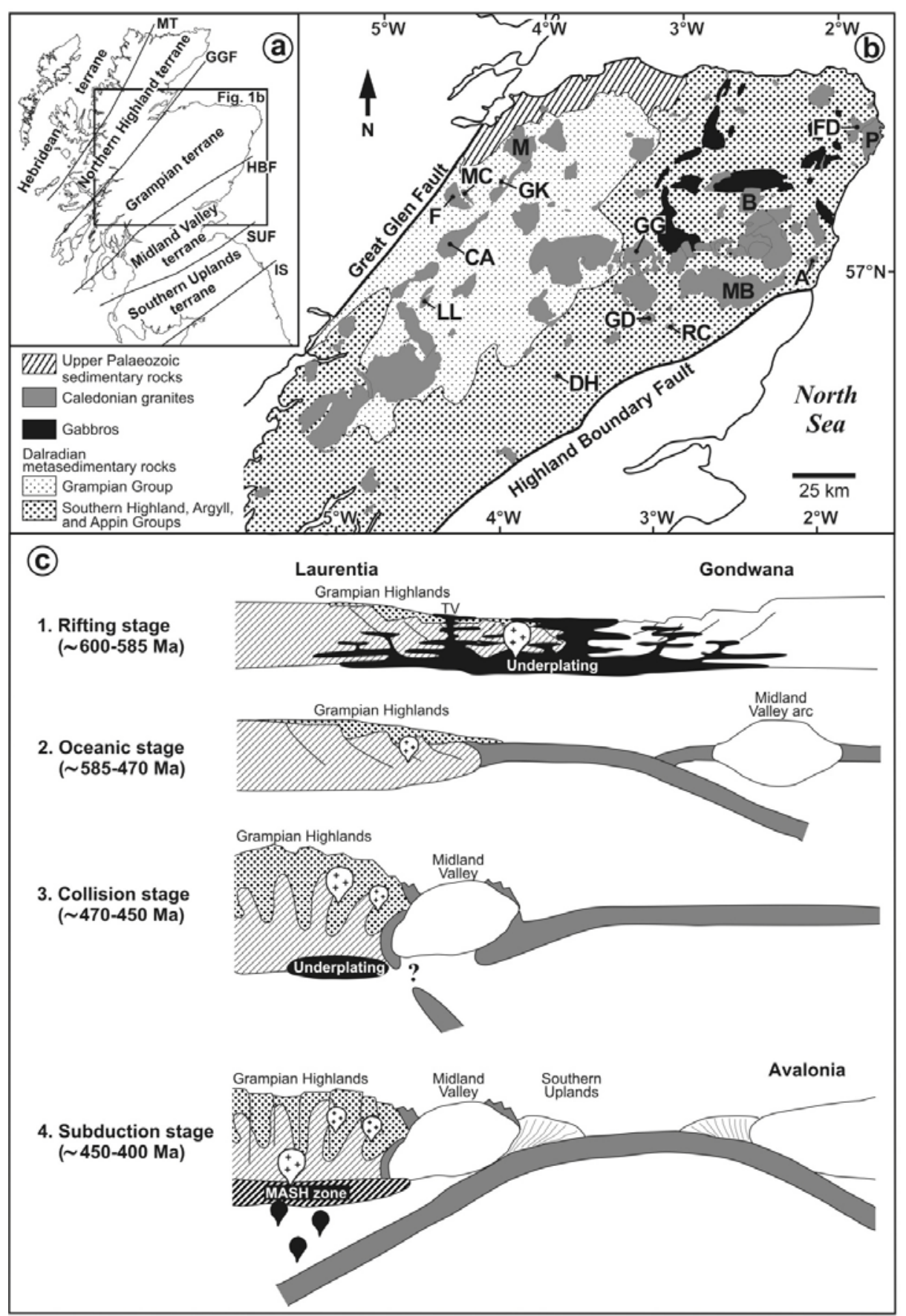

Figure 1: $\quad$ Maps showing the terranes of Scotland and major geological units of the Grampian Highlands. Inset (a) depicts the study area in the Grampian Highlands and adjacent lithotectonic terranes. Abbreviations: MT = Moine Thrust, GGF = Great Glen Fault, HBF = Highland Boundary Fault, SUF = Southern Upland Fault, and IS = Iapetus Suture. (b) Geological map of the Grampian Highlands (modified after Stephenson and Gould, 1995). The sampled intrusions are indicated: LL = Loch Laggan, $\mathrm{CA}=$ Crom Allt, $\mathrm{F}=$ Foyers, $\mathrm{MC}=$ Moal Chnoc, GK = Glen Kyllachy, M = Moy, $\mathrm{DH}=$ Dunfallandy Hill, GD = Glen Doll, RC = Rough Craig, GG = Glen Gairn, MB = Mount Battock, A = Auchlee, FD = Forest of Deer, and P = Peterhead. (c) Model for the geodynamic evolution of the Grampian Highlands modified after Oliver (2001; 2003) and Oliver et al. (2008). See text for discussion. The Grampian Highlands are shown as a composite block consisting of Dalradian metasedimentary rocks (stippled) and pre-Dalradian basement (hatched). 


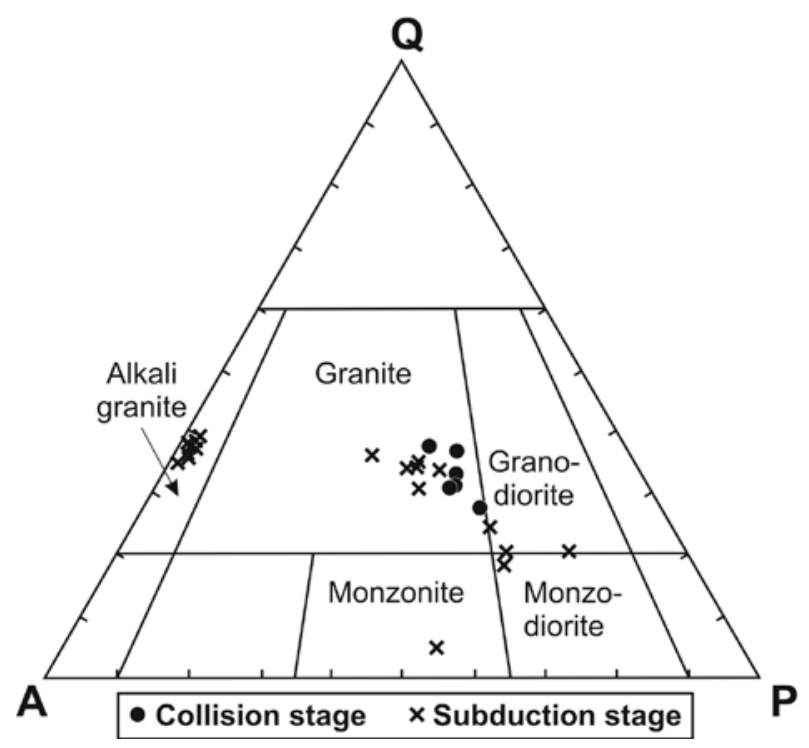

Figure 2: Normative mineralogical composition of granitoids from the Grampian Highlands plotted according to Streckeisen (1976) and LeMaitre (2002). Abbreviations: $\mathrm{Q}=$ quartz, $\mathrm{A}=$ alkali feldspar, $\mathrm{P}=$ plagioclase. Collision-related granitoids are classified as typical granites. Subductionrelated rocks are compositionally more diverse including granites, alkali-granites, granodiorite, monzonite, and monzodiorite.

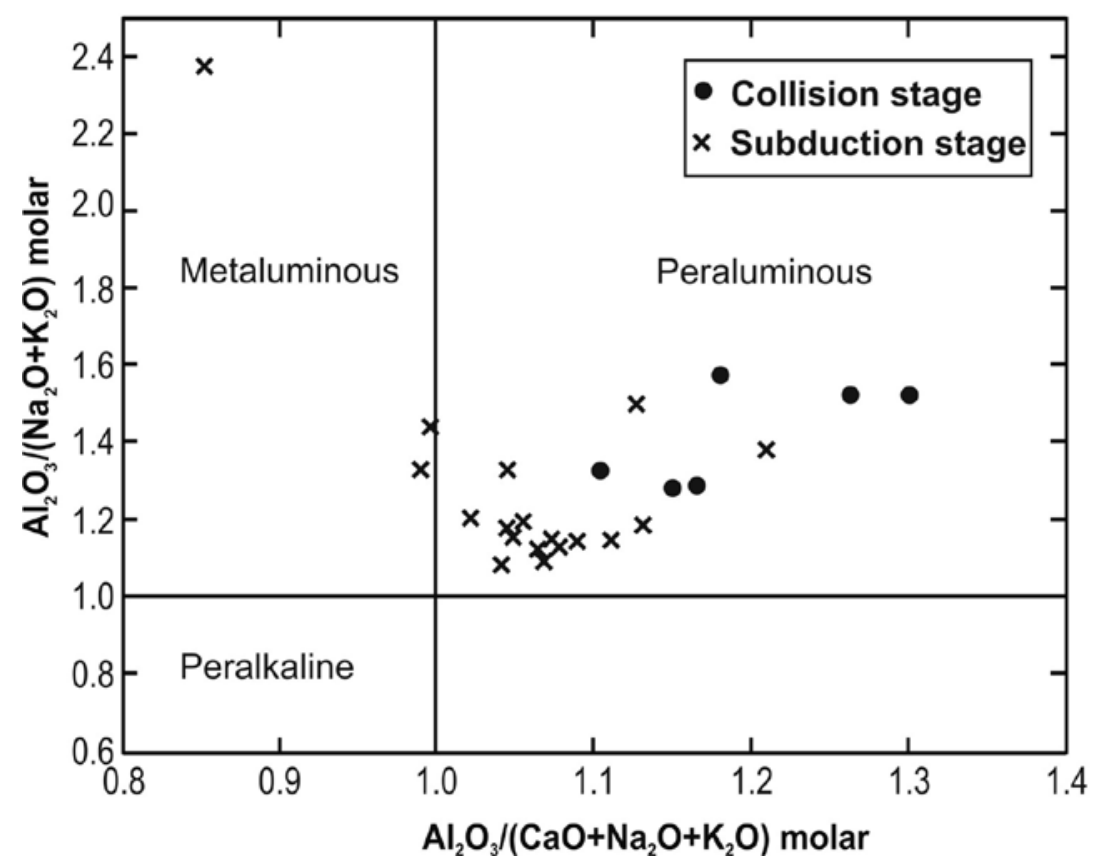

Figure 3: Aluminium saturation indices (Shand's Index) defined as $\mathrm{Al}_{2} \mathrm{O}_{3} /\left(\mathrm{CaO}+\mathrm{Na}_{2} \mathrm{O}+\mathrm{K}_{2} \mathrm{O}\right)=\mathrm{A} / \mathrm{CNK}$ of Clarke (1981) versus $\mathrm{Al}_{2} \mathrm{O}_{3} /\left(\mathrm{Na}_{2} \mathrm{O}+\mathrm{K}_{2} \mathrm{O}\right)=\mathrm{ASI}$ of Zen (1986). Collision-related granitoids have a distinct peraluminous composition typical for S-type granites. Subduction-related rocks are overall less peraluminous and include slightly metaluminous I-type granitoids. 

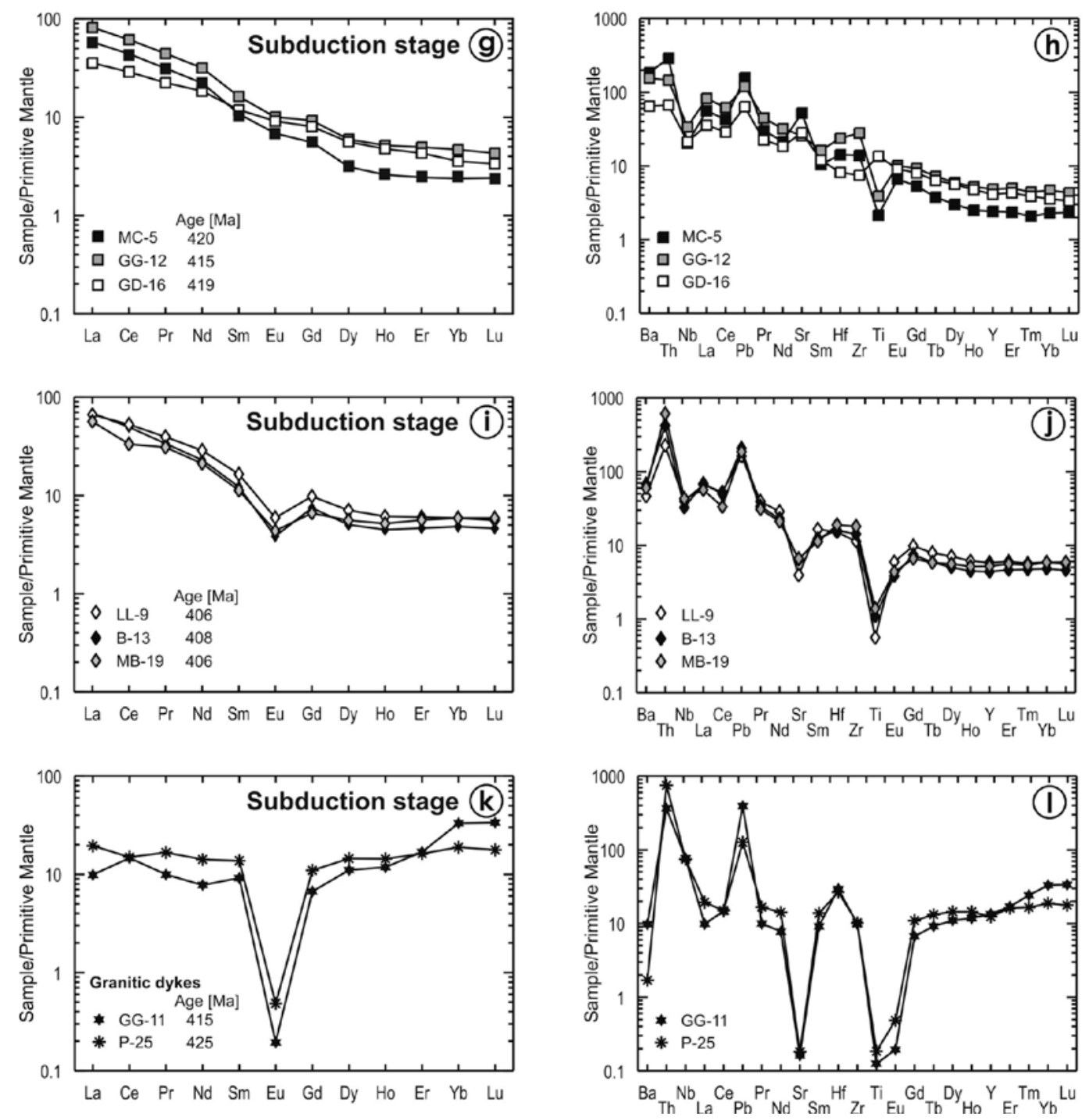

Figure 4: Normalized rare-earth- and extended trace-element patterns for granitoids of the Grampian Highlands. The data are grouped with respect to their emplacement ages and inferred tectonic settings (Oliver et al. 2008). Element concentrations for the primitive-mantle are from McDonough \& Sun (1995). 




Figure 5: Nd-isotope evolution diagram for granitoids of the Grampian Highlands. Filled circles represent the data of this study and open circles are published values (Hamilton et al. 1980; Halliday 1984; Clayburn 1988) recalculated with the SHRIMP zircon ages (Oliver et al., 2008). Bars on the right indicate the range in $\varepsilon_{\mathrm{Nd}}$ values of possible source rocks at $650 \mathrm{Ma}$ : D=Dalradian metasedimentary rocks (Frost \& O’Nions 1985; O’Nions et al. 1983) and G = Grenvillian rocks from the Grenville Province in eastern Canada (Dickin \& McNutt 1989; Daly \& McLelland 1991; Dickin \& Higgins 1992; Dickin 1998; Dickin 2000) and R=Rhinns block, possibly representing the basement of the NW Grampian Highlands (Marcantanio et al. 1988; Dickin \& Bowes 1991; Muir et al. 1994). In addition, isotopic ranges are shown for the Tayvallich volcanics (Halliday et al. 1989) and the Lorne lavas (Thirlwall 1982). These samples represent to some extent depleted upper mantle compositions. The line extending from the data fields on the right indicate the isotopic evolution of the basement units; the depleted mantle curve is from DePaolo (1981). 


\section{Table 1}

Sampled intrusions, age references, rock types, sample locations and descriptions

\section{Collision stage}

Rough Craig: $511 \pm 37$ Ma, sample RC-15, z, SHRIMP, Oliver et al. (2008)
RC-15
Granite
NO 350729

Foliated grey medium-grained granitoid consisting of alkali-feldspar (35\%), plagioclase (25\%), quartz (25\%), muscovite (10\%), and biotite (5\%).

Dunfallandy Hill: $481 \pm 15 \mathrm{Ma}$, wr, Rb/Sr, Pankhurst \& Pidgeon (1976)

$\begin{array}{lll}\text { DH-1 } & \text { Granite } & \text { NN } 939552 \\ \text { DH-2 } & \text { Granite } & \text { NN } 942550\end{array}$

Foliated medium-grained granite samples of slightly pink colour with $50 \%$ quartz, $25 \%$ plagioclase, $20 \%$ alkalifeldspar and $5 \%$ muscovite.

Auchlee: $475 \pm 12 \mathrm{Ma}$, sample A-14, z, SHRIMP, Oliver et al. (2008)
A-14
Granite
NO 894980

Unfoliated grey medium-grained sample with following major mineral phases: quartz (40\%), plagioclase (35\%), alkali-feldspar (20\%) and biotite and muscovite (together 5\%).

Glen Kyllachy: $451 \pm 4$ Ma, sample GK-3, z, SHRIMP, Oliver et al. (2008)
GK-3
Granite
$\mathrm{NH} 730257$

Unfoliated grey coarse-grained porphyritic granite made of alkali-feldspar (40\%), plagioclase (30\%), quartz (20\%), biotite (5\%), muscovite (5\%), and accessory chlorite.

Moy: $452 \pm 3$ Ma, sample M-4, z, SHRIMP, Oliver et al. (2008)
$\mathrm{M}-4$
Granite
$\mathrm{NH} 812335$

Unfoliated coarse-grained pink granite with reddish alkali-feldspar phenocrysts consisting of quartz (30\%), plagioclase (30\%), alkali-feldspar (25\%), biotite (10\%), muscovite $(5 \%)$.

\section{Subduction stage}

Peterhead: ca. $425,{ }^{40} \mathrm{Ar} /{ }^{39} \mathrm{Ar}$, Torsvik (unpubl. data)

$\begin{array}{lll}\text { P-22 } & \text { Alkali granite } & \text { NK } 135468 \\ \text { P-23 } & \text { Alkali granite } & \text { NK } 135468 \\ \text { P-24 } & \begin{array}{l}\text { Granite } \\ \text { Alkali granite } \\ \text { (dyke) }\end{array} & \text { NK } 241458 \\ \text { P-25 } & \begin{array}{l}\text { Alkali granite } \\ \text { (dyke) }\end{array} & \text { NK } 126414 \\ \text { P-26 } & \text { NK } 126415 \\ \text { P-27 } & \text { Granite } & \text { NK } 126416\end{array}$

Pink unfoliated coarse-grained porphyric granitoid with felsic xenoliths. Sample P-22, P-23, P-25 and P-26 consists mainly of alkali-feldspar (50\%), quartz (40\%), plagioclase $(5 \%)$ and biotite $(5 \%)$ whereas P-24 and P-27 contain equal proportion of alkali-feldspar and plagioclase. $\mathrm{P}-25$ and $\mathrm{P}-26$ are from a small microgranitic dyke.

Moal Chnoc: $420 \pm 3$ Ma, sample MC-5, z, SHRIMP, Oliver et al. (2008)
MC-5
Granodiorite
$\mathrm{NH} 587215$

Unfoliated pink medium-grained granitoid with 50\% plagioclase, 25\% alkali-feldspar, 20\% quartz, and 5\% biotite and muscovite.

New zircon SHRIMP data by Oliver et al. (2008) are given with uncertainties of $2 \sigma$. Abbreviations: $\mathrm{z}=$ zircon, $\mathrm{wr}=$ whole rock (no isochron), $\mathrm{m}=$ monazite 


\section{Table 1}

continued

$\begin{array}{ccc}\text { Foyers: } & 424 \pm 4 \text { Ma, sample F-6, z, SHRIMP, Oliver et al. (2008) } \\ \text { F-6 } & \text { Granite } & \text { NH } 539187 \\ \text { F-7 } & \text { Monzonite } & \text { NH } 549205\end{array}$

Unfoliated coarse-grained granitoid with following major mineral phases: quartz (20\%), plagioclase (45\%), alkalifeldspar (30\%), and biotite (5\%).

Glen Doll: $419 \pm 5$ Ma, sample GD-16, z, SHRIMP, Oliver et al. (2008)
GD-16
Granodiorite
NK 121481

Unfoliated grey medium-grained diorite consisting of biotite and hornblende beside the major minerals plagioclase (60\%), alkali-feldspar (20\%), and quartz (20\%).

Glen Gairn: ca. $415 \pm 1$ Ma, m, TIMS, Parry (unpubl. data, pers. comm., 2003)
GG-11
Alkali granite (dyke)
NJ 286003
GG-12
Granodiorite
NO 272993

Unfoliated pink porphyric granitoid consisting of plagioclase (40\%), alkali-feldspar (20\%), quartz (15\%), biotite (15\%), and hornblende (10\%)

Bennachie: $408 \pm 5$ Ma, sample B-13, z, SHRIMP, Oliver et al. (2008)
B-13
Granite
NJ 680185

Unfoliated pink coarse-grained granite made of smoky quartz (40\%), alkali-feldspar (30\%), plagioclase (20\%), biotite $(5 \%)$, and muscovite $(<5 \%)$.

Crom Allt: ca. 405 Ma, wr, Rb/Sr, Clayburn (1981)
CA-8
Monzodiorite
NH 544063

Slightly foliated grey medium-grained granitoid with 50\% plagioclase, 30\% alkali-feldspar, and 20\% quartz.

Loch Laggan: $406 \pm 14$ Ma, sample LL-9, z, SHRIMP, Oliver et al. (2008)
LL-9
Granite
NN 460850

Swarms of pink very fine-grained dykes and coarse-grained porphyritic pegmatites. The sample consists of quartz (40\%) and alkali-feldspar (60\%) occurring fine-grained and as phenocrysts.

Mount Battock: $406 \pm 5$ Ma, sample MB-19, z, SHRIMP, Oliver et al. (2008)

$\begin{array}{lll}\text { MB-17 } & \text { Alkali granite } & \text { NO } 651871 \\ \text { MB-18 } & \text { Alkali granite } & \text { NO } 663911 \\ \text { MB-19 } & \text { Alkali granite } & \text { NO } 651861\end{array}$

Unfoliated pink porphyric granitoid made of smoky quartz (40\%), alkali-feldspar (55\%), and biotite (5\%).

\section{Forest of}

$\underline{\text { Deer }}$

FD-21 Granite NK 053471

Unfoliated yellowish porphyric granite consisting of quartz (35\%), alkali-feldspar (30\%), plagioclase (30\%), and biotite $(5 \%)$. 
Table 2

Major and trace element concentrations of granitoids from the Grampian Highlands

\begin{tabular}{|c|c|c|c|c|c|c|c|c|c|c|c|c|c|}
\hline \multirow{2}{*}{$\begin{array}{l}\text { Stage } \\
\text { Sample }\end{array}$} & \multicolumn{6}{|c|}{ Collision stage } & \multicolumn{7}{|c|}{ Subduction stage } \\
\hline & $\mathrm{DH}-1$ & $\mathrm{DH}-2$ & GK-3 & M-4 & A-14 & RC-15 & MC-5 & $\mathrm{F}-6$ & $\mathrm{~F}-7$ & CA-8 & LL-9 & GG-11 & GG-12 \\
\hline \multicolumn{14}{|c|}{ Major elements [wt.\%] } \\
\hline $\mathrm{SiO}_{2}$ & 73.80 & 74.20 & 72.39 & 71.60 & 70.06 & 73.36 & 68.05 & 75.65 & 64.69 & 63.74 & 75.12 & 76.96 & 66.74 \\
\hline $\mathrm{TiO}_{2}$ & 0.04 & 0.06 & 0.10 & 0.42 & 0.52 & 0.15 & 0.43 & 0.18 & 0.20 & 0.56 & 0.11 & 0.03 & 0.78 \\
\hline $\mathrm{Al}_{2} \mathrm{O}_{3}$ & 15.18 & 15.01 & 15.56 & 14.46 & 15.23 & 15.29 & 15.57 & 13.16 & 19.01 & 17.85 & 13.18 & 12.84 & 15.31 \\
\hline $\mathrm{Fe}_{2} \mathrm{O}_{3}$ & 0.62 & 0.52 & 0.84 & 2.92 & 3.27 & 1.17 & 2.63 & 1.17 & 1.73 & 3.58 & 0.93 & 0.76 & 3.99 \\
\hline $\mathrm{MnO}$ & 0.01 & 0.01 & 0.02 & 0.03 & 0.05 & 0.02 & 0.04 & 0.03 & 0.03 & 0.07 & 0.05 & 0.08 & 0.07 \\
\hline $\mathrm{MgO}$ & 0.08 & 0.11 & 0.29 & 0.80 & 0.73 & 0.27 & 1.19 & 0.34 & 0.44 & 1.63 & 0.08 & 0.02 & 1.63 \\
\hline $\mathrm{CaO}$ & 0.67 & 0.72 & 1.30 & 1.08 & 1.78 & 0.96 & 2.20 & 0.76 & 2.14 & 2.18 & 0.79 & 0.34 & 2.60 \\
\hline $\mathrm{Na}_{2} \mathrm{O}$ & 4.25 & 4.30 & 4.52 & 3.51 & 3.43 & 3.33 & 4.69 & 3.89 & 4.69 & 4.60 & 3.49 & 4.32 & 3.84 \\
\hline $\mathrm{K}_{2} \mathrm{O}$ & 4.45 & 4.31 & 3.96 & 3.43 & 3.74 & 4.19 & 3.70 & 4.44 & 6.07 & 4.00 & 4.90 & 4.01 & 3.99 \\
\hline $\mathrm{P}_{2} \mathrm{O}_{5}$ & b.d. & b.d. & b.d. & 0.08 & 0.24 & 0.15 & 0.11 & b.d. & 0.02 & 0.39 & b.d. & b.d. & 0.22 \\
\hline LOI & 0.85 & 1.00 & 0.95 & 1.40 & 0.80 & 1.05 & 1.30 & 0.50 & 0.59 & 1.15 & 1.23 & 0.56 & 0.64 \\
\hline Total & 99.95 & 100.24 & 99.93 & 99.73 & 99.84 & 99.94 & 99.92 & 100.12 & 99.62 & 99.73 & 99.87 & 99.91 & 99.81 \\
\hline \multicolumn{14}{|c|}{ Trace elements [ppm] } \\
\hline $\mathrm{Ga}$ & 21 & 22 & 14 & 15 & 22 & 19 & 19 & 14 & 18 & 20 & 18 & 29 & 18 \\
\hline $\mathrm{Rb}$ & 240 & 260 & 87 & 116 & 138 & 163 & 67 & 71 & 63 & 97 & 184 & 1154 & 114 \\
\hline $\mathrm{Sr}$ & 85 & 103 & 389 & 403 & 280 & 134 & 1031 & 234 & 1282 & 1012 & 78 & 3 & 510 \\
\hline$Y$ & 6 & 3 & 13 & 15 & 17 & 13 & 10 & 5 & 6 & 21 & 25 & 58 & 21 \\
\hline $\mathrm{Zr}$ & 39 & 38 & 57 & 182 & 340 & 74 & 146 & 71 & 117 & 185 & 119 & 104 & 292 \\
\hline $\mathrm{Nb}$ & 8 & 9 & 5 & 8 & 25 & 13 & 13 & 6 & 5 & 11 & 26 & 50 & 22 \\
\hline $\mathrm{Ba}$ & 181 & 274 & 989 & 949 & 876 & 335 & 1218 & 633 & 6100 & 1573 & 306 & 65 & 1024 \\
\hline La & 3 & 5.74 & 11.3 & 28.7 & 59 & 15.0 & 36.2 & 11 & 29 & 13 & 42.9 & 6.39 & 53.2 \\
\hline $\mathrm{Ce}$ & 12 & 12.1 & 22.7 & 51.7 & 118 & 30.2 & 71.2 & 26 & 62 & 36 & 88.4 & 24.6 & 103 \\
\hline $\mathrm{Pr}$ & b.d. & 1.47 & 2.60 & 6.07 & 17 & 3.65 & 7.67 & 5 & b.d. & 17 & 10.0 & 2.53 & 11.3 \\
\hline $\mathrm{Nd}$ & 3 & 5.56 & 10.5 & 22.0 & 42 & 13.4 & 26.7 & 6 & b.d. & 21 & 35.8 & 9.73 & 39.8 \\
\hline $\mathrm{Sm}$ & & 1.46 & 2.33 & 3.65 & & 3.15 & 4.22 & & & & 6.68 & 3.72 & 6.59 \\
\hline $\mathrm{Eu}$ & & 0.40 & 1.16 & 1.40 & & 0.70 & 1.01 & & & & 0.91 & $<0.03$ & 1.55 \\
\hline $\mathrm{Gd}$ & & 1.30 & 2.21 & 2.90 & & 3.21 & 2.92 & & & & 5.32 & 3.64 & 5.04 \\
\hline $\mathrm{Tb}$ & & 0.17 & 0.34 & 0.41 & & 0.48 & 0.37 & & & & 0.78 & 0.91 & 0.71 \\
\hline Dy & & 0.73 & 2.15 & 2.59 & & 2.78 & 2.02 & & & & 4.76 & 7.43 & 4.00 \\
\hline $\mathrm{Ho}$ & & 0.09 & 0.47 & 0.54 & & 0.46 & 0.37 & & & & 0.91 & 1.76 & 0.77 \\
\hline $\mathrm{Er}$ & & 0.22 & 1.34 & 1.61 & & 1.15 & 1.03 & & & & 2.63 & 7.40 & 2.18 \\
\hline $\mathrm{Tm}$ & & 0.03 & 0.20 & 0.23 & & 0.15 & 0.14 & & & & 0.39 & 1.64 & 0.30 \\
\hline $\mathrm{Yb}$ & & 0.16 & 1.28 & 1.48 & & 0.81 & 1.01 & & & & 2.59 & 14.6 & 2.06 \\
\hline Lu & & 0.02 & 0.20 & 0.22 & & 0.10 & 0.16 & & & & 0.38 & 2.27 & 0.29 \\
\hline $\mathrm{Hf}$ & b.d. & 1.66 & 1.61 & 4.80 & 9 & 2.34 & 4.00 & b.d. & b.d. & 4 & 4.29 & 8.34 & 6.74 \\
\hline $\mathrm{Ta}$ & & 2.10 & 1.68 & 1.51 & & 2.06 & 2.14 & & & & 3.22 & 20.0 & 2.61 \\
\hline $\mathrm{Pb}$ & 51 & 49.4 & 28.9 & 15.1 & 23 & 29.7 & 23.8 & 22 & 23 & 22 & 24.2 & 58.7 & 18.0 \\
\hline Th & 2 & 2.60 & 3.18 & 7.25 & 15 & 3.93 & 23.0 & 6 & 5 & 2 & 17.9 & 29.1 & 11.5 \\
\hline
\end{tabular}

Sample names correspond to the abbreviations of intrusions in Fig.1. Major elements and gallium (Ga) were analysed by XRF. The trace elements of complete data sets were determined by ICP-MS, those of incomplete data sets by XRF. LOI, loss on ignition; b.d., below detection limit. 
Table 2

continued

\begin{tabular}{|c|c|c|c|c|c|c|c|c|c|c|c|c|}
\hline \multirow{2}{*}{$\begin{array}{l}\text { Stage } \\
\text { Sample }\end{array}$} & \multicolumn{12}{|c|}{ Subduction stage } \\
\hline & B-13 & GD-16 & MB-17 & MB-18 & MB-19 & FD-21 & $\mathrm{P}-22$ & $\mathrm{P}-23$ & $\mathrm{P}-24$ & $\mathrm{P}-25$ & P-26 & $\mathrm{P}-27$ \\
\hline \multicolumn{13}{|c|}{ Major elements [wt.\%] } \\
\hline $\mathrm{SiO}_{2}$ & 73.57 & 53.07 & 76.85 & 76.43 & 75.23 & 72.53 & 77.14 & 77.10 & 75.06 & 77.93 & 77.08 & 74.58 \\
\hline $\mathrm{TiO}_{2}$ & 0.22 & 2.72 & 0.14 & 0.16 & 0.28 & 0.30 & 0.10 & 0.11 & 0.18 & 0.04 & 0.05 & 0.19 \\
\hline $\mathrm{Al}_{2} \mathrm{O}_{3}$ & 13.64 & 14.74 & 12.66 & 12.93 & 13.00 & 14.12 & 12.11 & 12.16 & 12.94 & 12.29 & 12.31 & 12.99 \\
\hline $\mathrm{Fe}_{2} \mathrm{O}_{3}$ & 1.51 & 11.83 & 1.01 & 1.04 & 1.61 & 2.48 & 1.28 & 1.18 & 1.59 & 0.98 & 1.03 & 1.80 \\
\hline $\mathrm{MnO}$ & 0.05 & 0.15 & 0.03 & 0.02 & 0.02 & 0.03 & 0.01 & 0.01 & 0.03 & 0.01 & 0.01 & 0.01 \\
\hline $\mathrm{MgO}$ & 0.36 & 4.17 & 0.15 & 0.17 & 0.25 & 0.29 & 0.04 & 0.02 & 0.24 & 0.02 & 0.04 & 0.18 \\
\hline $\mathrm{CaO}$ & 1.09 & 6.10 & 0.29 & 0.28 & 0.17 & 0.80 & 0.28 & 0.27 & 0.60 & 0.11 & 0.24 & 0.45 \\
\hline $\mathrm{Na}_{2} \mathrm{O}$ & 3.53 & 2.52 & 3.43 & 3.57 & 3.44 & 2.60 & 2.76 & 3.08 & 3.57 & 3.99 & 3.86 & 3.49 \\
\hline $\mathrm{K}_{2} \mathrm{O}$ & 5.13 & 1.89 & 4.65 & 4.66 & 5.30 & 5.50 & 5.61 & 5.28 & 4.95 & 4.38 & 4.65 & 5.14 \\
\hline $\mathrm{P}_{2} \mathrm{O}_{5}$ & 0.02 & 0.12 & b.d. & b.d. & 0.03 & 0.10 & b.d. & b.d. & b.d. & b.d. & b.d. & 0.01 \\
\hline LOI & 0.77 & 2.03 & 0.74 & 0.69 & 0.59 & 1.20 & 0.70 & 0.80 & 0.90 & 0.50 & 0.66 & 0.99 \\
\hline Total & 99.88 & 99.34 & 99.94 & 99.96 & 99.91 & 99.94 & 100.03 & 100.00 & 100.06 & 100.24 & 99.92 & 99.82 \\
\hline \multicolumn{13}{|c|}{ Trace elements [ppm] } \\
\hline $\mathrm{Ga}$ & 19 & 19 & 20 & 20 & 17 & 20 & 21 & 21 & 21 & 25 & 25 & 21 \\
\hline $\mathrm{Rb}$ & 263 & 61 & 460 & 441 & 242 & 228 & 147 & 150 & 208 & 398 & 320 & 218 \\
\hline $\mathrm{Sr}$ & 127 & 558 & 67 & 77 & 131 & 123 & 29 & 28 & 44 & 4 & 8 & 43 \\
\hline $\mathrm{Y}$ & 19 & 18 & 18 & 17 & 22 & 25 & 50 & 52 & 54 & 53 & 41 & 52 \\
\hline $\mathrm{Zr}$ & 149 & 78 & 94 & 122 & 190 & 220 & 199 & 230 & 202 & 107 & 86 & 220 \\
\hline $\mathrm{Nb}$ & 21 & 14 & 36 & 35 & 28 & 23 & 14 & 32 & 29 & 49 & 44 & 33 \\
\hline $\mathrm{Ba}$ & 446 & 424 & 205 & 203 & 396 & 654 & 551 & 506 & 291 & 11 & 25 & 305 \\
\hline $\mathrm{La}$ & 44.5 & 23.1 & 25 & 34 & 36.7 & 38 & 61.0 & 61 & 41 & 12.6 & 7 & 61.3 \\
\hline $\mathrm{Ce}$ & 83.3 & 48.5 & 51 & 69 & 55.7 & 84 & 122 & 124 & 91 & 25.1 & 17 & 128 \\
\hline $\mathrm{Pr}$ & 8.56 & 5.70 & 2 & 2 & 7.85 & 8 & 17.1 & 15 & 9 & 4.24 & b.d. & 14.3 \\
\hline $\mathrm{Nd}$ & 28.7 & 23.0 & 9 & 10 & 26.3 & 34 & 70.1 & 45 & 36 & 17.7 & 6 & 52.7 \\
\hline $\mathrm{Sm}$ & 4.96 & 4.84 & & & 4.57 & & 15.4 & & & 5.58 & & 10.7 \\
\hline $\mathrm{Eu}$ & 0.59 & 1.40 & & & 0.67 & & 1.62 & & & 0.07 & & 0.87 \\
\hline $\mathrm{Gd}$ & 4.04 & 4.37 & & & 3.58 & & 13.2 & & & 5.96 & & 9.99 \\
\hline $\mathrm{Tb}$ & 0.58 & 0.63 & & & 0.57 & & 1.95 & & & 1.30 & & 1.56 \\
\hline Dy & 3.39 & 3.79 & & & 3.75 & & 11.0 & & & 9.74 & & 9.50 \\
\hline $\mathrm{Ho}$ & 0.67 & 0.71 & & & 0.77 & & 2.00 & & & 2.15 & & 1.88 \\
\hline $\mathrm{Er}$ & 2.04 & 1.89 & & & 2.45 & & 5.40 & & & 7.12 & & 5.40 \\
\hline $\mathrm{Tm}$ & 0.32 & 0.26 & & & 0.37 & & 0.70 & & & 1.12 & & 0.74 \\
\hline $\mathrm{Yb}$ & 2.12 & 1.58 & & & 2.59 & & 4.26 & & & 8.30 & & 4.92 \\
\hline Lu & 0.31 & 0.23 & & & 0.40 & & 0.59 & & & 1.20 & & 0.68 \\
\hline $\mathrm{Hf}$ & 4.51 & 2.31 & 4 & 5 & 5.35 & & 7.11 & 10 & 8 & 7.52 & 7 & 7.56 \\
\hline $\mathrm{Ta}$ & 3.07 & 1.33 & & & 3.75 & & 2.24 & & & 8.05 & & 3.78 \\
\hline $\mathrm{Pb}$ & 31.1 & 9.52 & 32 & 35 & 27.9 & & 25.8 & 32 & 24 & 19.0 & 31 & 22.7 \\
\hline Th & 33.5 & 5.33 & 31 & 38 & 48.6 & & 13.3 & 19 & 21 & 59.8 & 38 & 20.2 \\
\hline
\end{tabular}


Table 3

Sm and Nd isotopic data for granitoids from the Grampian Highlands

\begin{tabular}{|c|c|c|c|c|c|c|c|c|}
\hline Sample & Age [Ma] & Sm [ppm] & Nd [ppm] & ${ }^{147} \mathrm{Sm} /{ }^{144} \mathrm{Nd}$ & ${ }^{143} \mathrm{Nd} /{ }^{144} \mathrm{Nd}$ & $2 \sigma_{(\text {mean) }}$ & $\varepsilon_{\mathrm{Nd}(t)}$ & $\mathrm{T}_{\mathrm{DM}}[\mathrm{Ga}]$ \\
\hline \multicolumn{9}{|c|}{ Collision stage } \\
\hline $\mathrm{RC}-15$ & 511 & 3.55 & 16.98 & 0.1263 & 0.511683 & \pm 12 & -14.1 & 2.3 \\
\hline $\mathrm{DH}-2$ & 481 & 1.44 & 5.29 & 0.1646 & 0.511835 & \pm 12 & -13.7 & 2.3 \\
\hline$M-4$ & 452 & 3.89 & 25.03 & 0.0939 & 0.511759 & \pm 12 & -11.2 & 2.0 \\
\hline GK-3 & 451 & 1.99 & 9.26 & 0.1299 & 0.511866 & \pm 12 & -11.2 & 2.0 \\
\hline \multicolumn{9}{|c|}{ Subduction stage } \\
\hline P-22 & 425 & 12.29 & 72.23 & 0.1028 & 0.512165 & \pm 14 & -4.1 & 1.4 \\
\hline P-25 & 425 & 5.38 & 17.00 & 0.1912 & 0.512306 & \pm 12 & -6.2 & 1.6 \\
\hline P-27 & 425 & 10.69 & 52.57 & 0.1229 & 0.512080 & \pm 12 & -6.9 & 1.5 \\
\hline MC-5 & 420 & 3.99 & 25.96 & 0.0930 & 0.512201 & \pm 12 & -3.0 & 1.3 \\
\hline GD-16 & 419 & 4.75 & 22.87 & 0.1256 & 0.512141 & \pm 12 & -5.9 & 1.5 \\
\hline GG-11 & 415 & 3.71 & 9.94 & 0.2259 & 0.512388 & \pm 11 & -6.4 & 1.6 \\
\hline GG-12 & 415 & 6.41 & 37.93 & 0.1021 & 0.512272 & \pm 12 & -2.1 & 1.2 \\
\hline B-13 & 408 & 5.92 & 36.52 & 0.0981 & 0.512113 & \pm 12 & -5.1 & 1.5 \\
\hline MB-19 & 406 & 4.52 & 26.58 & 0.1028 & 0.512169 & \pm 12 & -4.3 & 1.4 \\
\hline LL-9 & 406 & 6.51 & 35.98 & 0.1094 & 0.512187 & \pm 12 & -4.3 & 1.4 \\
\hline \multicolumn{9}{|c|}{ Published data of following intrusions } \\
\hline Ben Vuirich $^{\mathrm{a}}$ & 590 & 8.54 & 38.70 & 0.1326 & 0.512137 & \pm 32 & -4.9 & 1.6 \\
\hline Strichen $^{a}$ & 467 & 8.04 & 44.67 & 0.1082 & 0.511821 & \pm 16 & -10.7 & 2.0 \\
\hline Aberdeen $^{\mathrm{a}}$ & 470 & 11.40 & 57.08 & 0.1212 & 0.511766 & \pm 41 & -12.5 & 2.1 \\
\hline Strathspey ${ }^{\mathrm{b}}$ & 449 & 3.01 & 19.00 & 0.0957 & 0.511735 & \pm 23 & -11.8 & 2.1 \\
\hline \multirow{2}{*}{$\begin{array}{l}\text { Findhorn }{ }^{c} \\
\text { Strath } \\
\text { Ossian }\end{array}$} & 443 & 2.59 & 11.14 & 0.1407 & 0.411930 & \pm 18 & -10.7 & 2.0 \\
\hline & 428 & 5.24 & 23.33 & 0.1357 & 0.512151 & \pm 20 & -6.2 & 1.6 \\
\hline Foyers $^{\mathrm{a}}$ & 426 & 9.93 & 59.90 & 0.0996 & 0.512009 & \pm 30 & -7.0 & 1.7 \\
\hline Foyers $^{a}$ & 426 & 12.50 & 72.05 & 0.1043 & 0.511963 & \pm 24 & -8.1 & 1.8 \\
\hline Foyers $^{a}$ & 426 & 4.48 & 34.04 & 0.0792 & 0.511883 & \pm 29 & -8.3 & 1.8 \\
\hline Foyers $^{a}$ & 426 & 1.77 & 12.69 & 0.0839 & 0.511971 & \pm 22 & -6.9 & 1.7 \\
\hline Foyers $^{a}$ & 426 & 2.42 & 16.71 & 0.0870 & 0.511993 & \pm 31 & -6.6 & 1.6 \\
\hline Foyers $^{a}$ & 426 & 1.76 & 13.06 & 0.0811 & 0.512026 & \pm 26 & -5.7 & 1.6 \\
\hline Lochnagar $^{c}$ & 417 & 5.06 & 30.21 & 0.1012 & 0.512236 & \pm 22 & -2.8 & 1.3 \\
\hline Hill of Fare ${ }^{c}$ & 403 & 5.11 & 25.51 & 0.1210 & 0.512339 & \pm 31 & -1.9 & 1.3 \\
\hline
\end{tabular}

$\varepsilon_{\mathrm{Nd}(\mathrm{t})}$ values were calculated for magmatic ages (see Table 1 for references). $\mathrm{T}_{\mathrm{DM}}$ ages were calulated according to the two-stage model of Liew \& Hofmann (1988). The model considers two stages of differentiation, seperation to a depleted mantel reservoir and to a continental crust reservoir. Isotopic data of a) Hamilton et al. (1980), b) Clayburn (1988), and c) Halliday (1984) were recalculated with the new zircon ages reported by Oliver et al. (2008). The $\varepsilon_{\mathrm{Nd}(\mathrm{t})}$ values of Aberdeen and Lochnagar intrusions were calculated with the monazite ages of Kneller \& Aftalion (1987) and Parry (pers. com.). The initial ratio of Ben Vuirich granite is based on the TIMS zircon age of Roger et al. (1989). 